\title{
Liderlik ve yetenek geliştirme programlarının performansa etkisi: Perakende satış temsilcileri üzerine bir araştırma
}

\section{The effect of leadership and talent development programs on performance: A research on retail sales representatives}

\author{
Egemen Ünal ${ }^{1}$ \\ Oya Erdil ${ }^{2}$
}

Hüseyin İnce ${ }^{3}$

\author{
${ }^{1}$ Doktora Öğrencisi, Gebze Teknik \\ Üniversitesi, Türkiye, \\ mail@egemenunal.com
}

ORCID: 0000-0002-2405-0200

2 Prof. Dr., Gebze Teknik Üniversitesi, Türkiye, erdil@gtu.edu.tr

ORCID: 0000-0003-3793-001X

3 Prof. Dr., Gebze Teknik Üniversitesi, Türkiye, h.ince@gtu.edu.tr

ORCID: 0000-0002-5953-6497

\section{Sorumlu Yazar/Corresponding Author:}

Egemen Ünal,

Gebze Teknik Üniversitesi, mail@egemenunal.com

Başvuru/Submitted: 2/04/2021

Revizyon/Revised: 1/05/2021

Kabul/Accepted: 7/05/2021

Yayın/Online Published: 25/06/2021

Atıf/Citation: Ünal, E., Erdil, O., İnce, H., Liderlik ve yetenek geliştirme programlarının performansa etkisi: Perakende satış temsilcileri üzerine bir araştırma, bmij (2021) 9 (2): 603-624, doi: https://doi.org/10.15295/bmij.v9i2.1808
Öz

$\mathrm{Bu}$ çalışmanın amacı, liderlik davranışlarının ve yetenek geliştirme programlarının satış temsilcilerinin algılanan (öznel) ve nesnel performansına etkisini incelemektir. Aynı zamanda performansın görev ve görev dışı boyutu ile nesnel performans arasındaki ilişki de incelenmektedir. Veri toplama süreci aralarında üç ay olan iki farklı dönemde gerçekleştirilmiştir. Türkiye' de faaliyet gösteren bir moda perakendesi firmasında çalışan 269 çalışan, ilgili yetenek geliştirme eğitiminde başarılı olmuş ve araştırmanın sonraki aşamalarında değerlendirmeye katılmıștır. Araştırmada; çalışanların kendini değerlendirdiği, yöneticilerin çalışanları değerlendirdiği ve çalışanların yöneticileri değerlendirdiği çeşitli anketler bilgisayar destekli sistemler aracıllı̆̆ ile uygulanmıştır. Araştırma sonuçlarına göre, hem görev ve ilişki odaklı liderlik davranışları hem de eğitim faaliyetleri performansı olumlu yönde etkilemektedir. Söz konusu nesnel performans olduğunda ise bu etki sadece eğitim faaliyetleri için geçerlidir. Ayrıca nesnel performans ile görev performansı arasında orta, nesnel performans ile bağlamsal performans arasında zayıf bir korelasyon tespit edilmiștir. Uygulayıcılar çalışanların nesnel performansını olumlu etkilemek için eğitim ve gelişim faaliyetlerine güvenebilirler. Çalışanların örgütsel vatandaşlık davranışlarında olumlu gelişmeler, ilişki odaklı liderlik davranışları ile sağlanabilir. Çalışma, liderlik davranışlarının ve eğitim değerlendirme seviyelerinin tamamının, farklı performans türleriyle ilişkisini tek bir araştırma içinde değerlendirerek sık rastlanmayan bir katkı ortaya koymayı hedeflemektedir.

Anahtar Kelimeler: Liderlik, Eğitim Değerlendirme, Görev Performansı, Bağlamsal Performans, Nesnel Performans

Jel Kodlari: M12, M53, D23

\begin{abstract}
This study aims to examine the effects of leadership behaviours and talent development programs on the perceived (subjective) and objective performance of sales representatives. At the same time, the relationship between the task and non-task dimension of performance and objective performance is also examined. The data collection process was carried out in two different periods, three months apart. A total of 269 sales employees of a fashion retail firm operating in Turkey who have successfully related talent development training participated in the study. In the research, various surveys in which employees rate themselves, supervisors rate employees and employees rate supervisors were applied through computer-based systems. According to the research findings, both task-oriented and relationship-oriented leadership behaviours and training activities positively affect performance. However, when it comes to objective performance, this effect is only valid for training activities. In addition, a moderate correlation was found between objective performance and task performance, and a weak correlation with objective performance and contextual performance. Therefore, practitioners can rely on training and development activities to positively influence the objective performance of employees. In addition, positive developments in employees' organizational citizenship behaviours can be achieved through relationship-oriented leadership behaviours. The study aims to reveal a unique contribution by evaluating the relationship of leadership behaviours and all levels of training evaluation with different types of performance in a single study.
\end{abstract}

Keywords: Leadership, Training Evaluation, Task Performance, Contextual Performance, Objective Performance

Jel Codes: M12, M53, D23 


\section{Extended Abstract}

\section{The effect of leadership and talent development programs on performance: A research on retail sales representatives}

\section{Literature}

\section{Research subject}

Various dynamics can positively affect the job performance of sales representatives working in the retail sector, whose core competency field is selling products or services to consumers. However, two assumptions of relationship draw attention between practitioners and researchers: the effect of team leaders (store managers) on employee performance and talent development efforts on employee performance. There is a lot of evidence in the literature for both interactions.

The main subject of the study is to examine these relationships with their widely accepted conceptualizations in the literature. Yukl's three-dimensional leadership model (Yukl, 2012; Yukl et al., 2002), which includes Task, Relationship and Change Oriented Leadership Behaviours, was taken as a basis for the leadership behaviours. In order to evaluate the training process, Kirkpatrick's four-level assessment model (D. L. Kirkpatrick, 1977; D. L. Kirkpatrick and Kirkpatrick, 2006, 2007), which includes the Reaction, Learning, Behaviour and Result levels, was used. Both Objective and Perceptual Performance measurements are used for job performance.

\section{Research purpose and importance}

This study examines the effects of leadership behaviours and talent development projects on the perceived (subjective) and objective performance of sales representatives. At the same time, the relationship between the task and non-task dimensions of performance and objective performance is also examined.

\section{Contribution of the article to the literature}

The study aims to reveal a distinctive contribution by evaluating the relationship of leadership behaviours and all levels of training evaluation with different types of performance in a single study.

\section{Design and method}

\section{Research type}

This research was conducted using quantitative research methods and techniques. Data were mainly collected by survey technique. Also, some kinds of data were taken directly from company records.

\section{Research problems}

The research seeks answers to the following questions: Is there a relationship between leadership behaviours and employee performance? Which kind of leadership behaviours affects employee performance? Is there a relationship between training programs and employee performance? Is there a relationship between the evaluation levels of the training programs?

In order to conduct research on the problems described above, it is necessary to access the same sample at two different times, which is not the case in most studies.

\section{Data collection method}

The data collection process was carried out in two different periods, three months apart. A total of 269 sales employees of a fashion retail firm operating in Turkey, who has successfully related talent development training, participated in the study. In the research, various surveys in which employees rate themselves, supervisors rate employees and employees rate supervisors were applied through computer-based systems.

\section{Quantitative/qualitative analysis}

Several quantitative methods were used in the study: Descriptive Statistics, Reliability Analysis with Alpha Model, Principal Component Analysis, Factor Analysis, Independent Sample T-Test and Paired Sample T-Test, Pearson Correlation Analysis, Simple and Multiple Linear Regression Analysis

\section{Research hypotheses}

The research hypotheses are determined as follows:

HEMEM-EOGR: Training satisfaction positively affects learning the content of the training.

HEIK-EOGR: Meeting training needs positively affects learning the content of the training.

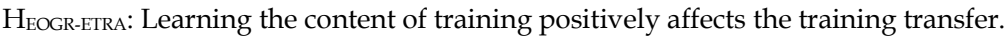

HEOGR-EDD: Learning the content of training positively affects the training behaviour change.

HETRA-PNES: Training transfer positively affects objective performance.

HEDD-PNES: Training behaviour change positively affects objective performance.

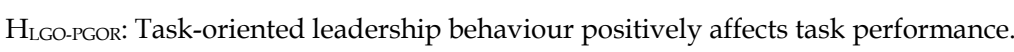

HLGO-PBAG: Task-oriented leadership behaviour positively affects contextual performance.

$\mathrm{H}_{\text {LGO-PALG: }}$ Task-oriented leadership behaviour positively affects perceived performance.

HLGO-PNES: Task-oriented leadership behaviour positively affects its objective performance. 
HLIO-PGOR: Relationship-oriented leadership behaviour positively affects task performance.

HLIO-PBAG: Relationship-oriented leadership behaviour positively affects contextual performance.

HLIO-PALG: Relationship-oriented leadership behaviour positively affects perceived performance.

HLIO-PNES: Relationship-oriented leadership behaviour positively affects objective performance.

HLDO-PGOR: Change-oriented leadership behaviour positively affects task performance.

HLDO-PBAG: Change-oriented leadership behaviour positively affects contextual performance.

HLDO-PALG: Change-oriented leadership behaviour positively affects perceived performance.

HLDO-PNES: Change-oriented leadership behaviour positively affects its objective performance.

\section{Findings and discussion}

\section{Findings as a result of analysis}

The results found in some analyses that are not included in the hypothesis test results are as follows: The objective and task performance averages of the employees who completed the training are higher than the employees who did not. Employees' selfassessment averages are higher than managers' assessment of them. However, there is a moderate correlation between the two measurement sources. Measures of leadership with a team perspective and individual perspective have different variances, so they give different results in hypothesis tests.

\section{Hypothesis test results}

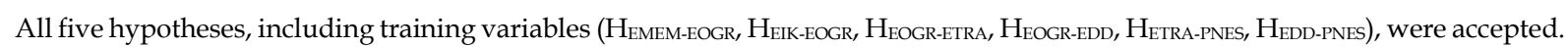

Based on a team-perspective leadership measure, four hypotheses ( $\mathrm{H}_{\text {LGO-PGOR, }} \mathrm{H}_{\text {LGO-PALG }}, \mathrm{H}_{\text {LIO-PBAG }}$, $\mathrm{H}_{\text {LIO-PALG }}$ ) related to the effect of the task-oriented and relationship-oriented leadership behaviours on performance were accepted, while the other four $\left(\mathrm{H}_{\mathrm{LGO}}\right.$ PBAG, $\mathrm{H}_{\text {LGO-PNES, }} \mathrm{H}_{\text {LIO-PGOR, }} \mathrm{H}_{\text {LIO-PNES}}$ ) were not approved. On the other hand, all four hypotheses of change-oriented leadership (H $\mathrm{H}_{\text {LDO-PGOR, }} \mathrm{H}_{\text {LDO-PBAG, }} \mathrm{H}_{\text {LDO-PALG, }} \mathrm{H}_{\text {LDO-PNES }}$ ) were rejected.

\section{Discussing the findings with the literature}

The results confirm the Kirkpatrick training evaluation paradigm. Also, the relationship between Relationship Oriented Leadership and Contextual Performance and the relationship between Task-Oriented Leadership and Task Performance confirms the literature.

In the results of the hypothesis, it was determined that Change Oriented Leadership did not give the expected results in models. For a "Change Oriented Leader" to be successful, it may be necessary to be equipped with more complex responsibilities and powers, such as an executive manager, rather than a limited job area such as a lower-level manager and related responsibilities.

\section{Conclusion, recommendation and limitations}

\section{Results of the article}

According to the research findings, both task-oriented and relationship-oriented leadership behaviours and training activities affect performance positively. However, when it comes to objective performance, this effect is only valid for training activities. In addition, a moderate correlation was found between objective performance and task performance, and a weak correlation with objective performance and contextual performance.

\section{Suggestions based on results}

Practitioners can rely on training and development activities to positively influence the objective performance of employees. In addition, positive developments in employees' organizational citizenship behaviours can be achieved through relationshiporiented leadership behaviours.

\section{Limitations of the article}

The critical research limitation is that the research was tested for a single type of training. Therefore, to generalize the results, its adoption in different types of training and different business areas is required in future research. In addition, no relationship of change-oriented leadership hypothesized concerning previous studies has not been confirmed. 


\section{Giriş}

Örgütlerin başarısı ile bireylerin başarısı arasında yüksek bir ilişki olduğu düşünüldüğünde çalışanların iş performansı, organizasyon için kritik önem arz etmektedir. Çalışanların iş performanslarının örgütün bütününün başarısı için önem derecesi, kurumun faaliyet gösterdiği sektör ile çalışanın rol ve sorumluluklarına göre değişiklik gösterir. Bu çerçevede perakende organizasyonlarında çalışan satış temsilcilerinin iş performansları, kurumun finansal performansı ile diğer sektör ve pozisyon alternatiflerinin birçoğuna göre daha yüksek bir ilişki içindedir. Temel yetkinlik alanı tüketiciye ürün veya hizmet satışı yapmak olan perakende sektöründe çalışan satış temsilcilerinin iş performanslarını olumlu etkileyebilecek çeşitli dinamikler bulunmaktadır.

Literatürde hem çalışanların iş performansı hem de özelde satış temsilcilerinin iş performansı ile ilgili araştırmalara çokça rastlanmaktadır. Bununla birlikte uygulayıcılar ve araştırmacılar arasında iki farklı ilişki varsayımı öne çıkmaktadır: Takım liderlerinin (mağaza yöneticilerinin) çalışan performansına etkisi ve yetenek geliştirme programlarının çalışan performansına etkisi.

Çalışmanın temel amacı; perakende sektöründe çalışan satış temsilcileri için yukarıda ifade edilen Liderlik-Performans ve Eğitim-Performans ilişkilerini literatürde yaygin kabul görmüş kavramsallaştırmalarıyla incelemektir. Bu çerçevede liderlik davranışları için Yukl'ın; Görev, İlişki ve Değişim Odaklı Liderlik davranışlarını barındıran üç boyutlu liderlik modeli temel alınmıştır. Eğitim sürecini değerlendirme için ise Kirkpatrick'in; Tepki, Öğrenme, Davranış ve Sonuç aşamalarını barındıran dört seviyeli değerlendirme yaklaşımı temel alınarak incelemeler gerçekleştirilmiştir. İş performansı için hem Nesnel hem de Öznel (Algılanan) Performans ölçümlenmesi hedeflenmiştir.

Çalışma birkaç farklı açıdan literatüre katkı sağlamayı hedeflemektedir. Araştırma, liderlik davranışlarının (Görev, İlişki ve Değişim Odaklı Liderlik) ve eğitim değerlendirme seviyelerinin (Tepki, Öğrenme, Davranış ve Sonuç) tamamının, farklı performans türleriyle ilişkisini tek bir araştırma içinde değerlendirerek sık rastlanmayan bir katkı ortaya koymaktadır. Buna yakın çalışmaların "yöneticilerin eğitime verdiği destek" veya "insan kaynakları bölümünün eğitim ve geliştirme çalışmalarından bütünleşik memnuniyet" bileşenleri ile sınırlı kaldığı düşünüldüğünde bu kapsamda bir araştırmaya literatürde rastlanmamıştır.

Çalışmayı benzer çalışmalardan ayıran bir diğer özgün değer de ölçüm kaynaklarının ve ölçüm dönemlerinin çeşitliğidir. Veriler iki farklı dönemde toplanmıştır. Bununla birlikte kişilerin kendilerini değerlendirdiği ve yöneticilerin çalışanları değerlendirdiği anketlere ek; liderlik davranışları, liderin takipçilerinin ortak görüşü olarak değerlendirilmiştir. Teknik zorluklar barındıran böyle bir veri toplama sürecine sahip çalışmalara literatürde sıkça rastlanmamaktadır. Ölçüm kaynakları ve ölçüm döneminin çeşitliliği temel ilişkilerin yanı sıra bazı ek incelemelere de olanak tanımıştır: Eğitimi tamamlayan ve tamamlamayan çalışanların performansları arasındaki fark; Algılanan performansın çalışanın kendi kendine değerlendirmesi ile yöneticinin çalışanı değerlendirmesi arasındaki ilişki; Takım ve birey perspektifli liderlik değerlendirmelerinin temel ilişkilere etkisi.

Son olarak, Türkçe literatürde Kirkpatrick'in eğitim değerlendirme modelinde yer alan dört seviyenin tamamının değerlendirildiği bir çalışmaya rastlanmamıştır. Yabancı literatürde ise dört seviyenin tamamının ölçümlendiği araştırmalar kısıtlıdır. Benzer biçimde, araştırma Yukl'ın Liderlik Davranış Sınıflandırmasının genişletilmiş 2017 sürümünün Türkçe literatürde ilk kullanıldığı çalışmalardan biridir.

Çalışmanın bölümleri şu şekilde düzenlenmiştir: İlk bölümde; araştırmanın üç ana değişkeni olan Liderlik Davranışları, Eğitim Süreci ve İş Performansı konusunda kavramsal bir çerçeve çizilmesi planlanmış, bununla birlikte araştırmanın uygulama alanı olan Kişisel Satış sürecine kısaca değinilmiştir. Takip eden bölümde; araştırmanın veri toplama süreci ve ölçme araçları hakkında bilgi verilmiş, sonraki bölümde ilgili ilişkiler incelenmiş ve bulgular açıklanmıştır. Son bölümde bulunan sonuçlar değerlendirilmiş, araştırmanın kısıtları ve öneriler paylaşılmıştır.

\section{Kavramsal çerçeve}

\section{Kişisel satış süreci}

Kişisel satış sürecinin endüstriyel satış ve perakende satış odaklı tanımlamaları olsa da süreçte yer alan adımlar büyük benzerlikler içermektedir. Özellikle ilk ve son adımları perakende odaklı, diğer adımları tüm kişisel satış süreçlerini kapsayacak biçimde satış süreci adımlarının şu başlıklardan oluştuğu söylenebilir: (1) Mağazanın ve satıcının hazırlığı, (2) Müşterinin karşılanması ve ilişki kurma, (3) Müşterinin ve ihtiyaçlarının anlaşılması, (4) Ürün veya hizmetin sunumu ve demonstrasyon, (5) Satış kapama, (6) İtirazların üstesinden gelme, (7) Müşteriyi uğurlama ve satış sonrası takip (Castleberry ve 
Tanner, 2011; Futrell, 2011; Johnston ve Marshall, 2016; Soysal, 2005; Spiro, Rich, ve Stanton, 2008; Vedamani, 2017).

Araştırmada performansa etkisi incelenen eğitim; yukarıda ifade edilen satış sürecine ait bilgi, beceri ve yetenekleri çalışanlara aktarmayı hedeflemektedir. Bu çerçevede araştırmanın "Eğitim Tepkisi", "Eğitim İçeriğini Öğrenme" ve "Eğitim Davranış Yansıması" ölçümleri bu sürece ait detayları barındırmaktadır.

\section{Performans}

İş Performansı; bireylerin kontrolünde olan ve örgütün amaçlarına katkıda bulunan faaliyetlerdir (Rotundo ve Rotman, 2002), serbest yerine içerik temelli hedeflerle ölçümlenebilir olmalıdır (Campbell ve Wiernik, 2015) ve sadece “Görev Performansı" (Murphy, 1990) değildir.

İş performansı ile ilgili hem genel hem de kişisel satış literatüründe çeşitli sınıflandırma çalışmaları ile ilgili tartışmaların çoğu; performansın davranış mı çıktı mı temelli olması gerektiği ile öznel (kalitatif, algısal) mi nesnel (kantitatif) mi ölçümler ile yapılması gerektiği üzerinedir (Anderson ve Oliver, 1987; Binning ve Barrett, 1989; Boles, Donthu, ve Lohtia, 1995; Castleberry ve Tanner, 2011; Futrell, 2011; Ingram, LaForge, Avila, Schwepker, ve Williams, 2020; Johnston ve Marshall, 2016; Spiro vd., 2008). Davranış bazlı performans ölçüm araçları kişilere belirli sorumluluklar verirken, çıktı bazlı sistemler "bir şekilde hedefe ulaşma" ilkesiyle yeni yollar keşfedebilmeyi sağlar. Aynı zamanda çıktı bazlı ölçümler uygulamada bütçelerle bağlantılı olduğundan aktif bir finansal ödüllendirme ile daha kolay ilişkilendirilebilir.

Nesnel performans kriterlerini belirlerken sadece örgüt hedeflerini ifade eden geniş kapsamlı ölçüm araçları yerine çalışanların kontrolünde olan kriterleri belirlemek esas olmalıdır. Araştırmalar nesnel performans ile öznel performans arasında düşük veya orta seviyede ilişkiye işaret etse de çoğu zaman birbirlerinin yerine kullanılamayacağı iddia edilmiştir (Bommer, Johnson, Rich, Podsakoff, ve Mackenzie, 1995; Jaramillo, Carrillat, ve Locander, 2005; Lowery ve Krilowicz, 1994; Plouffe, Hulland, ve Wachner, 2009; Rich, Bommer, Mackenzie, Podsakoff, ve Johnson, 1999).

Öznel performans uygulamaları farklı sınıflandırmalar barındırsa da çalışmalar; Görev ve Görev Dışı davranış/performans ayrımı ile paralel bir taksonomiye işaret etmektedir (Campbell, Gasser, ve Oswald, 1996; Campbell ve Wiernik, 2015; Harari, Reaves, ve Viswesvaran, 2016; Murphy, 1990; Viswesvaran ve Ones, 2000). Görev Dışı davranışları diğer bir ifade ile örgütsel vatandaşlık davranışlarını kavramsallaştırmak için birbirinden etkilenen ve birbirini geliştiren birkaç farklı model oluşturulmuştur (Borman ve Motowidlo, 1997; Brief ve Motowidlo, 1986; Organ, 1997, 2018; Organ, Podsakoff, ve MacKenzie, 2006; P. M. Podsakoff, Scott B. MacKenzie, Paine, ve Bachrach, 2000; Rogelberg, 2007). Bu araştırma, görev dışı performansı "Bağlamsal Performans" ifadesi ile ele almaktadır. Bunun en temel nedeni; bağlamsal performans kavramsallaştırmasının doğasında "performans" ölçümünü örtülü biçimde barındırması, diğer örgütsel vatandaşlık kökenli kavramların daha çok "davranış" tanımı olarak ifade edilmesi gösterilebilir. Literatürde bağlamsal performansın iş performansından ayrıştığına dair çokça araştırmaya rastlanabilir (Borman ve Motowidlo, 1997). Kavramın isimlendirilmesi, yapının doğru ölçümlenmesine göre çok daha az önemlidir (Motowidlo, 2000). Buna paralel olarak ölçüm araçları bölümünde detaylı ifade edileceği gibi bağlamsal performans ölçüm araçları örgütsel vatandaşlık ölçüm araçlarıyla benzerlik göstermektedir. Görev dışı performans veya davranış ile ilgili teorik çerçeve yorumlaması ve uygulama alanıyla ilgili felsefi anlamda ilginç bir paradoks bulunmaktadır. Görev dışı performansın "görev dışı" adlandırılmasının sebebi; formal anlamda kurum veya yönetici tarafından önemsenmeyip ödüllendirilmemesidir. Bununla birlikte, günümüzde birçok organizasyonda gerek bağlamsal performans gerekse diğer örgütsel vatandaşlık davranışları, performans değerlendirme süreçlerinin bir parçası haline gelmekte, kurumlar yöneticilerine çalışanlarının bu davranışlarını övmesi konusunda telkinde bulunmaktadır. Bu durum kavramın ortaya çıkış tanımına aykırı bir ilişki zinciri ortaya koymaktadır.

Öznel performans ölçümlerinin yönetici tarafından değerlendirilmesi ile çalışan tarafından değerlendirilmesinin benzerlikleri ve farklılıkları üzerine de tartışmalar devam etmektedir. Çalışanın kendini değerlendirmesinin yukarı yönlü bir sapma hatasına yol açmadığını (Churchill, Ford, Hartley, ve Walker, 1985), yukarı yönlü bir ortalama değişikliği gerçekleşse bile bunun performans seviyelerinde bir değişiklik yaratmayacağını (Kuvaas ve Dysvik, 2009; Sharma, Rich, ve Levy, 2004) hatta nesnel performans ile kişinin kendi öznel değerlendirmesinin daha yüksek ilişkili olduğunu savunan araştırmalar (Levy ve Sharma, 1993) mevcuttur. Ayrıca çalışanların kendini değerlendirmesinin, yönetici değerlendirmelerine göre daha az "halo" hatası doğurduğuna dair çalışmalar bulunmaktadır (Cooper, 1981). Bu iddianın tersini savunan araştırmalar, argümanlarını daha çok "performans etkisine" (performance effect) yani düşük performanslıların "olandan daha yüksek", yüksek performanslıların 
"olandan daha düşük" değerlendirmesinin yarattığı "hataya" dayandırmaktadır. Bu etkinin, başka bir kaynağın (yönetici değerlendirmesi veya nesnel ölçümün) değerlendirmesi ile çalışanın kendini değerlendirmesi arasındaki farklılığı açıkladığını yorumlayan çalışmalar mevcuttur (Jaramillo, Carrillat, ve Locander, 2003; Jaramillo vd., 2005; Plouffe vd., 2009). Ek olarak çeşitli araştırmalarda (Conway ve Huffcutt, 1997; Salgado ve Moscoso, 2019; Viswesvaran, Ones, ve Schmidt, 1996) yöneticilerin gerçekleştirdiği değerlendirmelerin güvenilirliğinin daha yüksek olduğu doğrulanmıştır. Yukarıda ifade edilen yönetici/çalışan değerlendirmeleri arasındaki farklılığın "hata" olarak değerlendirilebilmesi için "yönetici değerlendirmesinin" esas/doğru olarak ele alınması da aslında başka bir tartışma alanıdır. Yine nesnel performansın esas/doğru olarak alınması için nesnel performansın da mümkün olduğunca öznel değerlendirmelerden arındırılması, bazı çalışmalarda olduğu gibi satış hedefleri veya maaş artışları gibi temeli yönetici yorumlamasına bağlı ölçümlerden farklılaşması gerekir (Sharma vd., 2004).

Birçok araştırma, bağlamsal performans ile nesnel performans ve yönetici tarafından ölçülen öznel performans arasında da pozitif ilişkiyi vurgulamış, bazıları yönetici değerlendirmelerinin, nesnel performansa göre bağlamsal performanstan daha çok etkilendiğini tespit etmiştir (Lowery ve Krilowicz, 1994; MacKenzie, Podsakoff, ve Fetter, 1991, 1993; N. P. Podsakoff, Whiting, Podsakoff, ve Blume, 2009). Diğer taraftan genel performans değerlendirmesinde görev performansının bağlamsal performansa göre daha yüksek bir öneme sahip olduğunu savunan araştırmalar da mevcuttur (Rotundo ve Sackett, 2002).

Performansın, öznel araçlarla görev ve bağlamsal (görev dışı) olarak farklı boyutlarının, nesnel performansla birlikte ölçümlenmesi farklı ilişkilerin incelenmesine olanak tanır. Bununla birlikte, çoğu çalışma örtülü veya açık biçimde öznel ölçümlerin hem yönetici hem de çalışan perspektifli değerlendirmelerinin kullanılmasını önermektedir (Churchill vd., 1985; Jaramillo, Carrillat, ve Locander, 2004; Kuvaas ve Dysvik, 2009; Plouffe vd., 2009). Performans ölçümlerinin hangi model veya bakış açısıyla ele alınacağı, ölçümün hangi amaçla yapıldı̆̆ıyla da ilişkilidir. Performans ölçümü; seçme ve yerleştirme süreçleri, kariyer planlama süreçleri, eğitim ve gelişim planlamasına girdi oluşturmak, genel bir geri bildirim süreci için veya akademik bir araştırma için gerçekleştiriliyor olabilir. Uygulamada farklı performans modelleri ve farklı ölçüm araçları sıklıkla bir arada kullanılmaktadır.

Bir başka tartışma alanı, performans ölçümlerinin tek bir birleşik puana birleştirilmesi konusundadır. Genel kabul gören çok boyutluluk yaklaşımının (Campbell vd., 1996; Campbell ve Wiernik, 2015) yanı sıra bazı çalışmalar (Viswesvaran, 1993; Viswesvaran, Schmidt, ve Ones, 2005; Viswesvaran ve Ones, 2000) tek bir genel faktörün varyansın önemli bir bölümünü açıkladığını ve bunun halo etkisi olmadığını iddia ederken, öncül bazı çalışmalar da (Brogden ve Taylor, 1950; Schmidt ve Kaplan, 1971) ekonomik tek bir ölçütün veya bileşik indeks ölçütünün performansı ifade etmek için kullanılabileceğini iddia etmektedir.

Yukarıda ifade edilen yaklaşım ve paradigmalar bir araya getirildiğinde iş performansı en geniş ve kapsayıcı biçimde şu şekilde sinıflandırılmıştır: (1) Nesnel Performans, (2) Öznel/Algılanan Performans. (2a) Görev Performansı, (2b) Görev Dışı/Bağlamsal Performans. Ayrıca öznel performansın yönetici veya çalışan tarafından değerlendiriliyor olması dikkate değer bir farklılık doğurur. Son olarak hem nesnel hem öznel performans ölçümlerinin, tek bir bileşik puan veya indeks ile ölçülebiliyor olup olmadığı sınıflandırmalar üstü bir tartışma konusudur.

Bu araştırmada; “Eğitim Kaynaklı Davranış Değişiminin” bütünsel olarak “İçeriği Öğrenme” değişkeni tarafından etkilenmesi tartışılmıştır. Aynı zamanda yine bütünsel olarak "Eğitim Kaynaklı Davranış Değişiminin" performans çıktılarını, bir başka deyişle "Nesnel Performansı" etkilediği araştırılmaktadır. Eğitim kaynaklı davranış değişiminin genel bir faktöre dayandığını varsaymak ve araştırmayı bu yönde şekillendirmek oldukça işlevseldir. Ayrıca bu araştırmada ortak öncülleri olan "Nesnel Performansa" ait alt değişkenler, bileşik ölçüt yaklaşımına paralel biçimde bir indeks olarak ele alınmıştır. Algılanan Performans ise araştırmada hem alt boyutlarıyla hem de bileşik ölçüt olarak ele alınmıştır.

\section{Eğitim}

Eğitim, performans iyileşmesiyle sonuçlanan becerilerin, kavramların veya tutumların edinilmesidir (Goldstein, 1980). Eğitim ve Geliştirme hakkında tarihsel olarak farklı odak alanları üzerinde çalışmalar gerçekleştirilmiştir (Bell, Tannenbaum, Kevin Ford, Noe, ve Kraiger, 2017).

Kirkpatrick'in dört seviyeli eğitim değerlendirme modeli (D. L. Kirkpatrick, 1977; D. L. Kirkpatrick ve Kirkpatrick, 2006, 2007) literatürdeki en kabul gören yaklaşımdır (Arthur, Bennett, Edens, ve Bell, 2003). Birbirlerini sıra ve nedensellik ilişkilisi ile takip eden model seviyeleri ve cevap aranan sorular şu şekilde özetlenebilir: 
1. Tepki: Katılımcılar katıldıkları program hakkında ne düşünüyor? Ne ölçüde memnunlar?

2. Öğrenme: Katılımcılar bilgi ve becerilerini ne ölçüde öğrendiler? Tutumları ne ölçüde değişti?

3. Davranış: Ĕ̆itim programına katılmalarının bir sonucu olarak katılımcıların iş davranışları ne ölçüde değişti?

4. Sonuçlar: Satış miktarı, verimlilik gibi sonuçlar eğitim programından ne ölçüde etkilendi?

Kişisel satış hakkındaki kapsamlı çalışmalar isim vererek veya vermeyerek Kirkpatrick'in dört seviyesini ifade etmektedir (Ingram vd., 2020; Johnston ve Marshall, 2016; Spiro vd., 2008). Bununla birlikte literatürde satış eğitimi üzerine görece daha az araştırmaya rastlanmaktadır (Singh, Manrai, ve Manrai, 2015).

Erffmeyer ve arkadaşlarının (Erffmeyer, Russ, ve Hair, 1991) satış eğitim programlarında Kirkpatrick Modelinin uygulamalarına dair yaptığı araştırmada 14 temel değerlendirme tekniği sıralanmıştır. Çalışmanın sonuçlarına göre dört seviyenin tümü (tepki, öğrenme, davranış ve sonuç) "önem" açısından 14 sıralanan yöntemin ilk yedisinde gözlemlenebilir. Ancak, "kullanım sıklığı" sıralaması açısından, ilk 4 tekniğin tümü tepki yaklaşımlarıdır, ardından 1 öğrenme ve 2 davranış ölçüsü gelir. Tepki ölçü teknikleri diğer yaklaşımlara göre çok daha sık kullanılmaktadır. Bu araştırma çalışması Erffmeyer ve arkadaşlarının (Erffmeyer vd., 1991) raporladığı ölçüm tekniklerinden birçoğunu kullanmaktadir.

Literatürde Eğitim ile Performans arasında olumlu bir ilişki olduğu beklentisi araştırmalarda sıklıkla karşılaşılan bir varsayımdır. Bununla birlikte, bu pozitif bulgu veya varsayımların ağırlıklı olarak bütünsel insan kaynakları eğitim paradigması ile ilişkili olduğunu belirtmek gerekir.

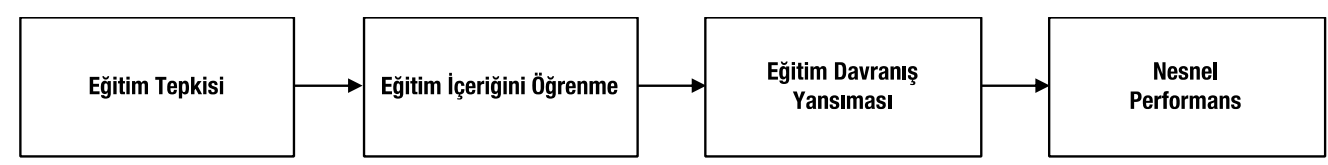

Şekil 1. Kirkpatrick Eğitim Değerlendirme Seviyeleri

Kirkpatrick modeli baz alınarak yapılan araştırmalar ise seviyeler arası ilişkileri incelemiştir. Kirkpatrick modelinin kendisi esasen davranış değişimi ile nesnel performans arasında bir ilişki varsayımı üzerine kuruludur. Diğer bir deyişle, Kirkpatrick'in 3. seviyesi ile 4. seviyesi arasında ilişkiden bahseden tüm çalışmalar aslında Eğitim ile Nesnel Performans arasındaki bir ilişkiden bahsetmiş olur. Geniş bir davranıssal paradigma yorumlamasıyla, 2. seviye ve 3. seviye arasındaki ilişkiyi inceleyen çalışmalar da "Öğrenme" ve "Davranışsal Performans" arasındaki ilişkiyi incelmiş olur (D. L. Kirkpatrick, 1977; D. L. Kirkpatrick ve Kirkpatrick, 2006, 2007). Bununla birlikte modelin dört seviyesinin tamamına yönelik çalışmalar sınırlıdır ve çoğu uygulama kolaylığından dolayı 1 . Seviye olan "Tepki" sonuçlarına odaklanmaktadır (Alliger, Tannenbaum, Bennett, Traver, ve Shotland, 1997; Alliger ve Janak, 1989). 2. seviye olan "Öğrenme" ile 3. seviye olan "Davranış" kavramsal olarak ilişkilendirilmiş olsa da ampirik ilişkilendirmede sınırlı bir başarı ortaya çıkmıştır (Arthur vd., 2003; J. D. Kirkpatrick ve Kirkpatrick, 2010).

Yukarıda özetlenen ilişkiler çerçevesinde Eğitim Seviyeleri ve Çıktı Performansı arasında Tablo 1'de ifade edilen hipotezler geliştirilmiştir.

Tablo 1. Eğitimle İlişkili Araştırma Hipotezleri

HEMEM-EOGR: Çalışanın eğitim memnuniyeti, eğitim içeriğini öğrenmesini pozitif yönde etkiler.

HEIK-EOGR: Çalışanın eğitim ihtiyaçlarının karşılanması, eğitim içeriğini öğrenmesini pozitif yönde etkiler.

HEOGR-ETRA: Çalışanin eğitim içeriğini öğrenmesi, eğitim transferini pozitif yönde etkiler.

HEOGR-EDD: Çalışanın eğitim içeriğini öğrenmesi, eğitim davranış değişimini pozitif yönde etkiler.

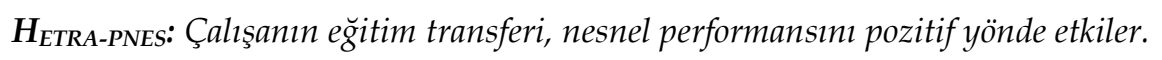

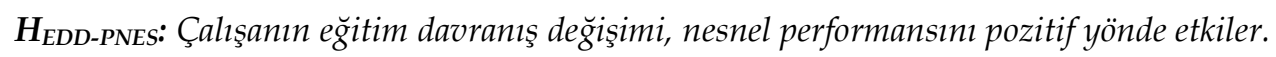

Kirkpatrick seviyeleri arasındaki ilişkilere odaklanmak yerine, eğitimi bütünsel bir kavram olarak ele alan bazı meta-analiz çalışmaları da, hem genel (Salas, DiazGranados, Klein, Burke, Stagl, Goodwin, ve 
Halpin, 2008; Thang, Quang, ve Buyens, 2010) hem de satış odaklı (Singh vd., 2015) eğitim faaliyetlerinin performansla pozitif bir ilişkisi olduğuna işaret etmektedir.

\section{Liderlik}

Liderlik, en kısa tanımıyla bireyleri ve grupları, ortak hedeflere ulaşmak amacıyla ile etkileme sürecidir (Bass ve Bass, 2008; Northouse, 2016; Yukl, 2013). Liderlik davranışları yaygın biçimde görev ve ilişki odaklı davranışlar olarak gruplanabilir ve 20. yüzyılın ortalarından itibaren geçmişte gerçekleştirilen birçok çalışma bu iki kategori ile benzer sinıflandırmayı içermektedir (Bass ve Bass, 2008; Kilburn, 2007; Yukl, 2013). Araştırmalarda değişim odaklı davranışların izlerine ise 1980'lerin sonundaki genel "değişim" rüzgârı ile uyumlu biçimde sonraki dönemlerde rastlanır (Ekvall ve Arvonen, 1991; Yukl, 1999).

Liderlik davranışlarıyla performans arasındaki ilişkiyi inceleyen birçok çalışma bulunmaktadır. Bu çalışmaların; bazıları iki boyutun yani görev ve ilişki odaklı liderlik davranışlarının performansla pozitif bir ilişkisinden bahsederken (Burke, Stagl, Klein, Goodwin, Salas, ve Halpin, 2006; Fisher ve Edwards, 1988; Özdevecioğlu ve Kanıür, 2009), bazıları ise her üç boyutun yani görev, ilişki ve değişim odaklı liderlik davranışlarının performansı (Borgmann, Rowold, ve Bormann, 2016; Fernandez, 2008) veya yönetsel etkililiği (Yukl, Mahsud, Prussia, ve Hassan, 2019) olumlu etkilediğini ifade eder. Değişim odaklı liderlik ile dönüşümcü liderliğin benzer dinamikleri barındırdığı düşünüldüğünde (Borgmann vd., 2016; Yukl, Gordon, ve Taber, 2002); dönüşümcü liderliğin genel performansa (Cummings, MacGregor, Davey, Lee, Wong, Lo, Muise, ve Stafford, 2010; Cummings, Tate, Lee, Wong, Paananen, Micaroni, ve Chatterjee, 2018; Ererdi ve Durgun, 2020) ve bağlamsal performansa (Cummings vd., 2018) olumlu etkisi araştırma hipotezleri açısından önemli sonuçlardır. Perakende ve satış alanlarına odaklanmış liderlik çalışmalarında da genel tablo benzerdir. Bazı araştırmalar tüm liderlik davranışlarının genel performansla pozitif bir ilişkisi olduğuna vurgu yaparken (Porr ve Fields, 2006; Tyagi, 1985), bazı çalışmalar da nesnel (DeClerk, 2007; MacKenzie, Podsakoff, ve Rich, 2001), öznel (Shannahan, Bush, ve Shannahan, 2013) ve bağlamsal (MacKenzie vd., 2001) performansın dönüşümcü liderlikle ilişkisinin etkileşimci liderliğe göre daha yüksek olduğunu tespit etmişlerdir.

Yukarıda özetlenen ilişkiler çerçevesinde Liderlik ve Performans arasında Tablo 2'de ifade edilen hipotezler geliştirilmiştir.

Tablo 2. Liderlikle İlişkili Araştırma Hipotezleri

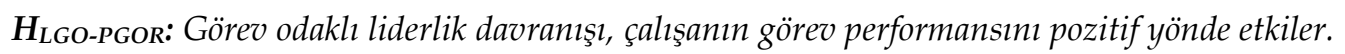

$H_{L G O-P B A G}$ Görev odaklı liderlik davranışı, çalışanın bağlamsal performansını pozitif yönde etkiler.

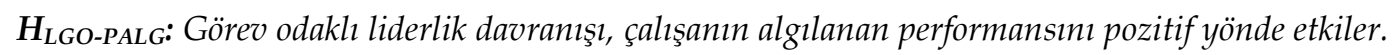

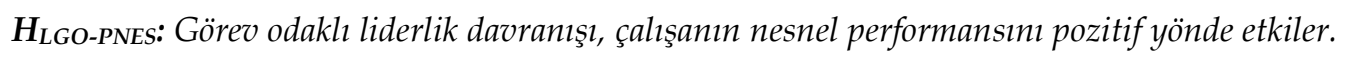

HLIO-PGOR: İlişki odakl liderlik davranışı, çalışanın görev performansını pozitif yönde etkiler.

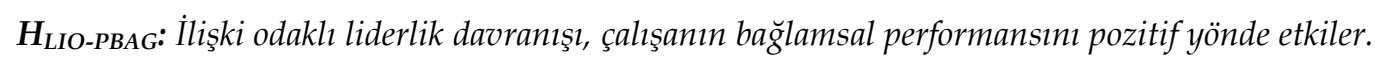

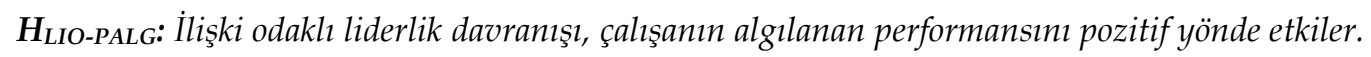

HLIO-PNES: Illişki odaklı liderlik davranışı, çalışanın nesnel performansını pozitif yönde etkiler.

HLDO-PGOR: Değisşim odakh liderlik davranışı, çalışanın görev performansını pozitif yönde etkiler.

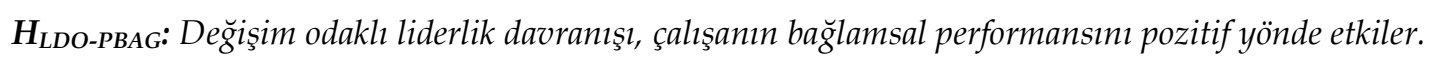

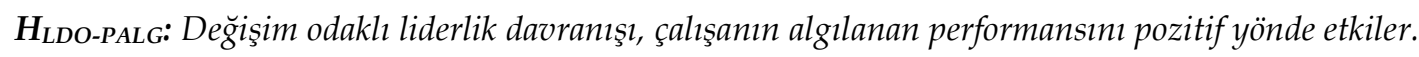

HLDO-PNEs: Değişim odaklı liderlik davranışı, çalışanın nesnel performansını pozitif yönde etkiler.

Diğer taraftan liderlik davranışlarının performansı etkileme incelemelerinde tutarlı bir öngörünün ortaya konma zorluklarını hatırlatan çalışmaların (Damayanti, Hartono, Wijaya, Helmi, ve Riyono, 2019; Uçar, Eren, ve Erzengin, 2012; Yukl vd., 2002) yanı sıra, bazı liderlik davranışlarının performansı olumsuz etkilediğini vurgulayan araştırmalar (Cummings vd., 2010, 2018; Mekraz ve Gundala, 2016) da mevcuttur.

Liderlik davranış sınıflandırmasında Yukl'ın üç boyutlu modeli alternatif sınıflandırmalara göre üstünlükler barındırmaktadır. Liderliğin etkinliğini yorumlamada dönüşümcü liderlik araştırmalarının aksine tarafsızdır (Avolio ve Bass, 2002), alt ve orta düzey yöneticiler için daha uygundur (Tracey ve Hinkin, 1998), ana davranış kategorilerinde sonuçları daha fazla etkilemektedir (Michel, Lyons, ve Cho, 
2011) ve birçok farklı liderlik davranışını açıklamak için yeterlidir (Borgmann vd., 2016). Zaman içerisinde Yukl, modelinde çeşitli geliştirmeler ve revizeler gerçekleştirmiştir (Yukl, 2012; Yukl vd., 2002).

$\mathrm{Bu}$ araştırma Yukl'ın 18 bileşenli davranış modelini temel alsa da çalışmanın ampirik modeli alt davranış bileşenlerini değil, ana kategorileri (meta kategorileri) esas almaktadır. Ayrıca Yukl'ın da önerdiği biçimde; mağaza yöneticilerinin yetki ve sorumluluk alanlarıyla ilgisiz ve uygun olmaması sebebiyle "Dış Çevre Odaklı Liderlik" meta kategorisi araştırma kapsamından çıkarılmış, böylece 3 değişken; "Görev Odaklı Liderlik Davranışı", "İlişki Odaklı Liderlik Davranışı" ve "Değişim Odaklı Liderlik Davranışı" olarak araştırmaya dahil olmuştur.
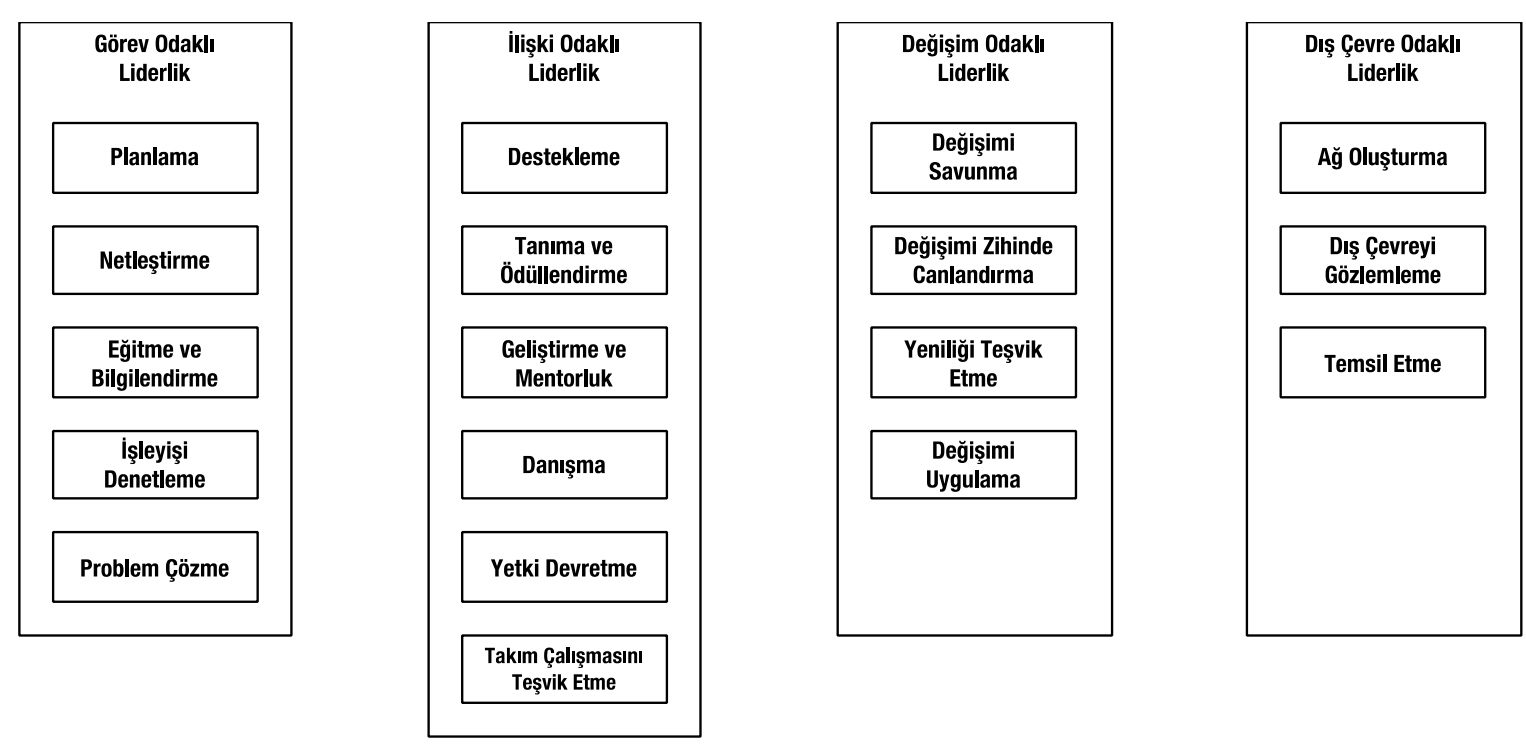

Şekil 2. Yukl Liderlik Davranış Sınıflandırması (2017)

\section{Araştırma}

\section{Örneklem}

Araştırmanın ana evreni; Türkiye'de faaliyet gösteren moda perakendesi zincir firmalarında çalışan, satış sürecinden sorumlu perakende satış danışmanı, satış sorumlusu veya satış personelleridir.

Araştırmanın "eğitim" değerlendirmesi boyutu iki farklı dönemde aynı örnekleme erişebilmeyi gerektirmektedir. Ayrıca araştırmanın "Liderlik Davranışları" ve "Algılanan Performans" değerlendirmeleri sebebiyle, çalışanlar ve yöneticilerinin çift yönlü bir eşleşme barındırması söz konusudur.

Yukarıda ifade edilen iki ihtiyacın sağlanabilmesi amacıyla toplam çalışan sayısı 500'ün üzerinde, satış danışmanı sayısı 350'nin üzerinde ve araştırma sırasında aktif mağaza sayısı 65 olan bir moda perakendesi firması belirlenmiştir. Firmanın yetenek geliştirme takvimi ile değerlendirme anketlerinin zamanlaması uyumlulaştırılarak hedeflenen araştırma gerçekleştirilmiştir.

\section{Veri toplama süreci}

Veri toplama süreci 2019 yılı içinde, iki farklı zamanda gerçekleştirilmiştir. Bu iki farklı zaman; "eğitimden hemen sonra" ve "eğitimden bir süre sonra" olarak özetlenebilir. Söz konusu süre özellikle eğitim sonrası davranış değişimlerinin gözlemlenebilmesi için 3 ay olarak belirlenmiştir. Ayrıca veri kaynağı olarak çalışanlar ve onların yöneticileri kullanılmıştır. Tablo 3, değişkenlerin veri kaynaklarını ve dönemlerini özetlemektedir.

Çalışanların kendilerini ve yöneticilerini değerlendirmelerine ek olarak yöneticilerin çalışanları değerlendiriyor olması yaygın "kâğıt-kalem" anketlerle karmaşık ve hatalara açık bir süreç olabilir. Bu sebeple bilgisayar destekli sistemler kullanılmıştır.

\section{Ölçme araçları}

Anket biçimde ölçülen tüm ifadeler 5'li Likert ile ölçülmüştür.

Liderlik davranışları ölçeği olarak Yukl'ın MPS çalışması kullanılmıştır (Yukl, 2012; Yukl vd., 2002). Kendisi ile yapılan telif hakkı ve ölçüm aracı yazışmalarında Yukl modelinin ve ölçüm aracının 2017 versiyonunu paylaşmaktadır. Örnek madde: Çalışanlara karşı anlayışlı ve destekleyicidir. 
Kirkpatrick'in modelinin ayrıntıları ve en iyi uygulama örnekleri birçok direkt ve endirekt kaynakta açıklanmaktadır. Kaynakların bazıları ölçüm araçlarının ilkelerini ortaya koyarken bazıları daha kapsamlı yol haritaları önermektedir (Alliger vd., 1997; Alliger ve Janak, 1989; D. L. Kirkpatrick ve Kirkpatrick, 2006, 2007).

Eğitim Memnuniyeti; bu ölçüm için Wilson (Wilson, 1999) tarafından geliştirilen ve 9 memnuniyet sıfatının değerlendirildiği araç kullanılmıştır. Örnek madde: Tamamlamış olduğum satış eğitiminin değerli olduğunu düşünüyorum.

Tablo 3. Değişkenler ve Veri Kaynakları

\begin{tabular}{|c|c|c|c|}
\hline Değişkenler & Dönem & Katılım/İşlenme Özel Şartları & Veri Kaynağı \\
\hline Eğitim Memnuniyeti & Eğitim Dönemi & - & Çalışan \\
\hline $\begin{array}{l}\text { Eğitim İhtiyacının } \\
\text { Karşılanması }\end{array}$ & Eğitim Dönemi & - & Çalışan \\
\hline Öğrenme & Eğitim Dönemi & $\begin{array}{l}\text { Eğitimin Tüm Modüllerinin } \\
\text { Başarıyla Tamamlanması }\end{array}$ & Nesnel \\
\hline Eğitim Transferi & Eğitim Sonrasında & $\begin{array}{l}\text { Eğitimin Tüm Modüllerinin } \\
\text { Başarıyla Tamamlanması }\end{array}$ & Çalışan \\
\hline Eğitim Davranış Değişimi & Eğitim Sonrasında & $\begin{array}{l}\text { Eğitimin Tüm Modüllerinin } \\
\text { Başarıyla Tamamlanması }\end{array}$ & Yönetici \\
\hline Değişim Odaklı Liderlik & Eğitim Sonrasında & $\begin{array}{l}\text { Belirli Bir Süre Yönetici-Çalışan } \\
\text { İlişkisinin Var Olması** }\end{array}$ & Çalışan (Ortalama Değer) \\
\hline Görev Odaklı Liderlik & Eğitim Sonrasında & $\begin{array}{l}\text { Belirli Bir Süre Yönetici-Çalışan } \\
\text { İlişkisinin Var Olması** }\end{array}$ & Çalışan (Ortalama Değer) \\
\hline İlişki Odaklı Liderlik & Eğitim Sonrasında & $\begin{array}{l}\text { Belirli Bir Süre Yönetici-Çalışan } \\
\text { İlişkisinin Var Olması** }\end{array}$ & Çalışan (Ortalama Değer) \\
\hline $\begin{array}{l}\text { Yönetici Perspektifli } \\
\text { Bağlamsal Performans }\end{array}$ & Eğitim Sonrasında & $\begin{array}{l}\text { Belirli Bir Süre Yönetici-Çalışan } \\
\text { İlişkisinin Var Olması** }\end{array}$ & Yönetici \\
\hline $\begin{array}{l}\text { Yönetici Perspektifli } \\
\text { Görev Performans }\end{array}$ & Eğitim Sonrasında & $\begin{array}{l}\text { Belirli Bir Süre Yönetici-Çalışan } \\
\text { İlişkisinin Var Olması** }\end{array}$ & Yönetici \\
\hline $\begin{array}{l}\text { Çalışan Perspektifli } \\
\text { Bağlamsal Performans }\end{array}$ & Eğitim Sonrasında & - & Çalışan \\
\hline $\begin{array}{l}\text { Çalışan Perspektifli } \\
\text { Görev Performans }\end{array}$ & Eğitim Sonrasında & - & Çalışan \\
\hline Nesnel Performans & Eğitim Sonrasında & - & Nesnel \\
\hline \multicolumn{4}{|c|}{$\begin{array}{l}\text { * "Eğitim Memnuniyeti” anketi } 9 \text { modülden oluşan eğitimin her modülünün sonunda tekrar eden } 9 \text { madde ile } \\
\text { cevaplanmıştır. Toplamda } 81 \text { soru cevaplanmış olsa da aynı soruların tüm eğitim için ortalaması alınarak } 9 \text { madde } \\
\text { analize tabi tutulmuştur. } \\
\text { ** Yönetici ile çalışanın en az } 45 \text { gün birlikte çalışmış olması kuralı uygulanmıştır. }\end{array}$} \\
\hline
\end{tabular}

Eğitim İhtiyacının Karşılanması; eğitim içeriğinde yer alan 9 farklı başlık için çalışanların eğitim ihtiyacının karşılanıp karşılanmadığı algısını ölçen indeks, Kirkpatrick'in ana hatları işaret ettiği kılavuza paralel olarak geliştirilmiştir (D. L. Kirkpatrick ve Kirkpatrick, 2006). Ayrıca bu yaklaşım Tannenbaum tarafından kavramsallaştırılan, katılımcıların beklenti ve isteklerinin ne kadarının karşılandığının ölçümlendiği yapı ile benzerlik göstermektedir (Tannenbaum, Mathieu, Salas, ve Cannon-Bowers, 1991). Her bölüm sonunda katılımcıya şu soru sorulmuştur: "Lütfen tamamlamış olduğunuz eğitim modülünün ilgili konuda eğitim ihtiyacınızı ne ölçüde karşıladığını belirtin."

Öğrenme Puanı; her bir modülün tamamlanması sonrasında eğitim içeriği ile ilgili yapılan temel değerlendirme notudur. Testte yer alan örnek bir soru şöyledir: Müşteriye "merhaba" dedikten sonra 1-2 saniye beklemelisiniz çünkü; (a) Çoğu müşteri ürünleri yalnızca inceler ve rahatsız edilmek istemez, (b) Diğer işlerinize geri dönmeniz gerekebilir, (c) Ardından ne söyleyeceğinizi bilmiyorsunuz, (d) Müşterinin yanıtına göre kendi yanıtınızı şekillendirebilirsiniz.

Eğitim Davranış Değişimi; ölçüm aracı için söz konusu eğitimin içeriği temel alınmış, bununla birlikte içerik olarak Spiro' nun (Spiro vd., 2008) kantitatif ölçüm araçları sınıflandırması, araç geliştirme bakış 
açısı olarak Behrman ve Perreault'ın (Behrman ve Perreault, 1982) çalışmalarından faydalanılmıştır. Örnek madde: Ürünü denemesi için müşteriyi teşvik eder.

Eğitim Transferi; literatür, uygulayıcı deneyimleri ve eğitim içerikleri göz önünde bulundurularak bir çalışma ekibi ile geliştirilen ölçüm aracı 11 ifadeden oluşmaktadır (D. L. Kirkpatrick ve Kirkpatrick, 2006; Wilson, Strutton, ve Farris, 2002). Örnek madde: Aldı̆̆ım eğitimdeki birçok öneriyi kendime ve şartlara uyarlayarak kullanabiliyorum.

Nesnel Performans verileri satış danışmanı bazında firmanın kasa-satış sistem kayıtlarından elde edilmiş ve dört temel sayısal performans göstergesi tespit edilmiştir: (1) Alı̧̧veriş Dönüşüm Oranı, (2) Ziyaretçi Başına Satış Oranı, (3) Ortalama Sepet Adedi, (4) Ortalama Sepet Tutarı

Ayrıca ölçümde hata payını azaltmak ve ölçüm başarısını kuvvetlendirmek amacıyla "Nesnel Performans" ölçümü belirli iki dönem arasındaki yükseliş veya azalışı temsil eden bir indekse dönüştürülmüş̧ür. Bu çerçevede önce çalışan bazlı; eğitim öncesi 3 ay ve eğitim sonrası 3 ay ortalamalar alınmış, sonrasında her değişken için artış veya azalış oranları bu ortalamalar üzerinden tespit edilmiştir. Son olarak bu artış oranları yeniden bir ortalamaya tabi tutularak bir indeks haline getirilmiş ve "Nesnel Performans Değeri" tespit edilmiştir.

Algılanan Performans iki alt bileşeniyle ele alınmıştır: (1) Görev Performansı, (2) Bağlamsal Performans

Hem Görev Performansı hem de Bağlamsal Performans için Goodman ve Svyantek (Goodman ve Svyantek, 1999) tarafından geliştirilen ölçek kullanılmıştır. Ölçeğin 9 maddesi görev performansını, 16 maddesi ise bağlamsal performansı ölçmektedir. Goodman and Svyantek'in oluşturduğu ölçeğin bağlamsal performans boyutu aslında Smith ve arkadaşlarının (Smith, Organ, ve Near, 1983) geliştirdiği örgütsel vatandaşlık davranışı ölçeğinin ifadelerinin geliştirilmiş bir versiyonudur. Ölçekte yer alan görev performansı boyutu ile ilgili örnek madde: "İş ile ilgili bütün görevlerde uzmanlık gösterir" ve bağlamsal performans boyutu ile ilgili örnek madde:" Diğer arkadaşları olmadığında, onların işlerine yardimcı olur"

\section{Analiz ve bulgular}

İki farklı anket yoluyla elde edilen değişkenlerin faktör analizi sonucunda (KMO: .852 ve KMO: .927) madde sayıları azaltılmış ve geriye kalan maddelerle yapılan iç tutarlılık analizinde değişkenler için en düşüğü .883 olan Cronbach's Alpha değerleri elde edilmiş, böylece araştırmanın istenen güvenilirlik değerlerine sahip olduğu kontrol edilmiştir. Tablo 4, faktör ve iç tutarlılık analiz özetini göstermektedir.

Tablo 4. Değişkenlerin Faktör Yükleri ve Cronbach's Alpha Değerleri

\begin{tabular}{|c|c|c|c|c|}
\hline Değişkenler & $\begin{array}{r}\text { Madde } \\
\text { Sayısı }\end{array}$ & $\begin{array}{r}\text { En Yüksek } \\
\text { Faktör Yükü }\end{array}$ & $\begin{array}{r}\text { En Düşük } \\
\text { Faktör Yükü }\end{array}$ & $\alpha$ \\
\hline \multicolumn{5}{|l|}{ Çalışan Perspektifli Değişkenler } \\
\hline Eğitim Memnuniyeti & 5 & .905 & .776 & .961 \\
\hline Eğitim İhtiyacının Karşılanması & 8 & .682 & .496 & .881 \\
\hline Eğitim Transferi & 11 & .861 & .542 & .967 \\
\hline Değişim Odaklı Liderlik & 12 & .866 & .718 & .970 \\
\hline Görev Odaklı Liderlik & 15 & .797 & .615 & .973 \\
\hline İlişki Odaklı Liderlik & 18 & .747 & .533 & .974 \\
\hline Çalışan Perspektifli Bağlamsal Performans & 15 & .783 & .491 & .934 \\
\hline Çalışan Perspektifli Görev Performansı & 9 & .730 & .583 & .944 \\
\hline \multicolumn{5}{|l|}{ Yönetici Perspektifli Değişkenler } \\
\hline Eğitim Davranış Değişimi & 33 & .845 & .484 & .977 \\
\hline Yönetici Perspektifli Bağlamsal Performans & 6 & .718 & .567 & .833 \\
\hline Yönetici Perspektifli Görev Performansı & 9 & .746 & .551 & .902 \\
\hline
\end{tabular}

Araştırma hipotezleri birden çok regresyon modeli ile incelenmiştir. Tablo 5, bu modelleri listelemektedir. 
Tablo 5. Araştırma Regresyon Modelleri

Model 1: Eğitim Tepkisinin Öğrenmeye Etkisi

Model 2.1: Öğrenmenin Eğitim Transferine Etkisi

Model 2.2: Öğrenmenin Eğitim Davranış Değişimine Etkisi

Model 3a: Eğitim Davranış Yansımasının ve Takım Perspektifli Liderliğin Nesnel Performansa Etkisi

Model 3b: Eğitim Davranış Yansımasının ve Birey Perspektifli Liderliğin Nesnel Performansa Etkisi

Model 4.1a: Takım Perspektifli Liderliğin Bağlamsal Performansa Etkisi

Model 4.2a: Takım Perspektifli Liderliğin Görev Performansına Etkisi

Model 4.3a: Takım Perspektifli Liderliğin Algılanan Performansa Etkisi

Model 4.1b: Birey Perspektifli Liderliğin Bağlamsal Performansa Etkisi

Model 4.2b: Birey Perspektifli Liderliğin Görev Performansına Etkisi

Model 4.3b: Birey Perspektifli Liderliğin Algılanan Performansa Etkisi

\section{Eğitimi tamamlama ve performans ilişkisi}

Sonuç hipotezlerinden biri olmasa da araştırma örtülü biçimde; söz konusu eğitimin tamamlanmış olması ile "performans" arasında bir ilişki olduğunu varsaymaktadır. Bunun için hipotez testlerine geçmeden "Eğitimi Tamamlayan" satış danışmanları ile "Eğitimi Tamamlamayan" satış danışmanlarının performansları arasında bir fark olup olmadığı incelenebilir.

Bağımsız örneklem T-Testi sonuçlarına göre, eğitimi tamamlayanların ( $\mathrm{O}=144,936, \mathrm{SS}=26,380)$, eğitimi tamamlamayanlara $(\mathrm{O}=136,494, \mathrm{SS}=24,794)$ göre Nesnel Performans ölçümlerinin ortalaması daha yüksektir $(\mathrm{t}(264)=2,436, \mathrm{p}=.008)$.

Benzer biçimde eğitimi tamamlayanların $(\mathrm{O}=3,753$, SS=0,625), eğitimi tamamlamayanlara $(\mathrm{O}=3,601$, $\mathrm{SS}=0,590)$ göre Yönetici Perspektifli Görev Performansı ölçümlerinin ortalaması daha yüksektir $(\mathrm{t}(242)=1,782, \mathrm{p}=.038)$.

Bu sonucu; -elbette nedensellik incelemesine ihtiyaç olmakla birlikte- en azından temel seviyede; içeriği performans artışına yönelik bir eğitimin, istatistiksel olarak performans artışı gerçekleştirebildiğine bir işaret olarak yorumlamak mümkündür.

\section{Çalışan ve yönetici perspektifli algılanan performans ilişkisi}

Literatürde çokça tartışılan bir konu olarak, çalışan ve yönetici perspektifinde yapılan değerlendirmeler arasındaki anlamlı bir farklılık olup olmadığı incelenebilir.

Bağımlı (İlişkili) örneklem T-Testi sonuçlarına göre hem Bağlamsal Performans ( $t(239)=4,774, p<.001)$ hem de Görev Performansı $(\mathrm{t}(239)=12,420, \mathrm{p}<.001)$ ölçümleri için çalışanın perspektifinden gerçekleştirilen ölçümler $\mathrm{p}<0.001$ anlamlılık seviyesinde daha yüksek ortalamaya sahiptir.

Bununla birlikte Bağlamsal Performansın ( $(238)=.344$, $\mathrm{p}<.01)$ ve Görev Performansının $(r(238)=.316$, p<.01) iki farklı perspektif ölçümleri arasında pozitif yönde ve orta seviyede bir korelasyon bulunmaktadır. Bu durum, -kullanım amacına göre değişmekle birlikte- literatüre paralel biçimde iki perspektifin, şartlar gerektirdiğinde birbiri yerine kullanılabilmesine olanak tanıdığı biçimde yorumlanabilir.

\section{Eğitim tepkisinin öğrenmeye etkisi}

Model 1, Eğitim Memnuniyetinin ve Eğitim Tepkisinin Eğitim İçeriğini Öğrenme üzerine etkisini incelemektedir. Modelin regresyon sonucuna göre, Eğitim Memnuniyeti $(\beta=.264, \mathrm{t}(266)=4.669, \mathrm{p}<.001)$ ve Eğitim İhtiyacının Karşılanması $(\beta=.381, \mathrm{t}(266)=6.729, \mathrm{p}<.001)$ değişkenleri bir arada Eğitim İçeriğini Öğrenme sonucunu pozitif yönde etkilemektedir $\left(R^{2}=.300, F(2,266)=57.091, p<.001\right)$.

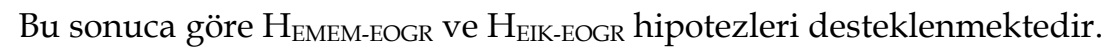

\section{Öğrenmenin eğitim davranış yansımasına etkisi}

Model 2.1, Eğitim İçeriğini Öğrenmenin Eğitim Transferine; Model 2.2, Eğitim İçeriğini Öğrenmenin Eğitim Davranış Değişimine etkisini incelemektedir.

Regresyon sonucuna göre, Eğitim İçeriğini Öğrenme $(\beta=.331, \mathrm{t}(161)=4.446, \mathrm{p}<.001)$ Eğitim Transferi sonuçlarını pozitif yönde etkilemektedir $\left(R^{2}=.109, F(1,161)=19.766, p<.001\right)$. Benzer şekilde Eğitim İçeriğini Öğrenme $(\beta=.375, \mathrm{t}(169)=5.264, \mathrm{p}<.001)$ Eğitim Davranış Değişimini pozitif yönde etkilemektedir $\left(\mathrm{R}^{2}=.141, \mathrm{~F}(1,169)=27,706, \mathrm{p}<.001\right)$. 
Bu sonuçlara göre $\mathrm{H}_{\text {EOGR-ETRA }}$ ve $\mathrm{H}_{\text {EOGR-EDD }}$ hipotezleri kabul edilmiştir.

\section{Ĕgitim davranış yansıması ve liderliğin nesnel performansa etkisi}

Literatürde liderlik araştırmalarında en yaygın kullanılan yöntem; "çalışanın perspektifinde yöneticisinin nasıl davrandığının" değerlendirilmesi olarak öne çıkmaktadır. Başta Yukl olmak üzere birçok araştırmacı ise en nesnel yöntem olarak -şartlar uygunsa- lider davranışlarının, aynı lidere bağlı izleyicilerin yorumlarının ortalaması olarak değerlendirilmesi olduğunu ifade etmektedir. Tablo 6, iki farklı değerlendirme biçimini açıklamaktadır.

Tablo 6. Birey ve Takım Perspektifli Liderlik Değerlendirmesi Örneği

\begin{tabular}{cc|c|c|c}
\hline Çalışan & $\begin{array}{c}\text { Ham Liderlik } \\
\text { Değerlendirmesi }\end{array}$ & Takım/Lider & $\begin{array}{c}\text { Birey Perspektifli } \\
\text { Liderlik Değerlendirmesi }\end{array}$ & $\begin{array}{c}\text { Takım Perspektifli } \\
\text { Liderlik Değerlendirmesi }\end{array}$ \\
\hline Ç1 & D1 & & D1 & ORTALAMA (D1,D2,D3) \\
Ç2 & D2 & L1 & D2 & ORTALAMA (D1,D2,D3) \\
\hline Ç3 & D3 & & D3 & ORTALAMA (D1,D2,D3) \\
\hline Ç4 & D4 & & D4 & ORTALAMA (D4,D5,D6) \\
\hline Ç5 & D5 & L2 & D5 & ORTALAMA (D4,D5,D6) \\
Ç6 & D6 & & D6 & ORTALAMA (D4,D5,D6) \\
\hline
\end{tabular}

Model 3, Eğitim Transferi, Eğitim Davranış Değişimi, Değişim Odaklı Liderlik, İlişki Odaklı Liderlik ve Görev Odaklı Liderliğin Nesnel Performans üzerine etkisini incelemektedir. Model 3a bu incelemeyi "Takım Perspektifli Liderlik Değerlendirmesi” üzerinden gerçekleştirirken, Model 3b "Birey Perspektifli Liderlik Değerlendirmesiyle" analizi gerçekleştirmektedir.

Model 3a regresyon sonucuna göre, Eğitim Transferi $(\beta=.259, \mathrm{t}(146)=3.447, \mathrm{p}<.01)$ ve Eğitim Davranış Değişimi $(\beta=.356, t(146)=4.681, p<.001)$ Nesnel Performans sonuçlarını pozitif yönde etkilemektedir. Sonuçlara göre Değişim Odaklı Liderlik, Görev Odaklı Liderlik ve İlişki Odaklı Liderliğin Nesnel Performans üzerinde anlamlı bir etkisi bulunmamaktadır $\left(\mathrm{R}^{2}=.249, \mathrm{~F}(5,146)=9.697, \mathrm{p}<.001\right)$.

Böylece Takım Perspektifli Liderlik değerlendirmesinde HETRA-PNES ve HEDD-PNEs: hipotezleri

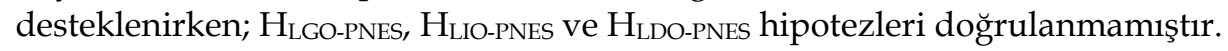

Model 3b regresyon sonucuna göre ise Eğitim Davranış Değişimi $(\beta=.204, \mathrm{t}(146)=2.080, \mathrm{p}<.05)$ ve İlişki Odaklı Liderlik $(\beta=.301, \mathrm{t}(146)=2.504, \quad \mathrm{p}<.05)$ Nesnel Performans sonuçlarını pozitif yönde etkilemektedir. Sonuçlara göre Eğitim Transferi, Değişim Odaklı Liderlik ve Görev Odaklı Liderliğin Nesnel Performans üzerinde anlamlı bir etkisi bulunmamaktadır $\left(\mathrm{R}^{2}=.286, \mathrm{~F}(5,146)=11.718, \mathrm{p}<.001\right)$.

Böylece, Birey Perspektifli Liderlik değerlendirmesinde $H_{\text {EDD-PNES }}$ ve $H_{\text {LIO-PNES }}$ hipotezleri kabul

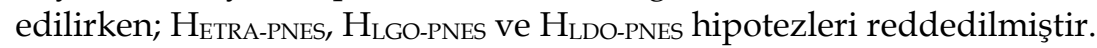

\section{Liderliğin algılanan performansa etkisi}

Değişim Odakı Liderlik, İlişki Odaklı Liderlik ve Görev Odaklı Liderliğin Bağlamsal Performans üzerine etkisi Model 4.1'de, aynı değişkenlerin Görev Performansına etkisi Model 4.2' de, yine aynı değişkenlerin Algılanan Performansa etkisi Model 4.3'te incelenmiştir. Model 4.1a, 4.2a ve 4.3a "Takım Perspektifli Liderlik Değerlendirmesi" üzerinden analizleri gerçekleştirirken, Model 4.1b, $4.2 \mathrm{~b}$ ve $4.3 \mathrm{~b}$ "Birey Perspektifli Liderlik" değişkenleriyle analizleri gerçekleştirmektedir.

Model 4.1a regresyon sonucuna göre İlişki Odaklı Liderlik $(\beta=.236, t(234)=2.219, p<.05)$ Bağlamsal Performans sonuçlarını pozitif yönde etkilemektedir. Değişim Odaklı Liderlik ve Görev Odaklı Liderliğin Bağlamsal Performans üzerinde anlamlı bir etkisi bulunmamaktadır $\left(R^{2}=.092, F(3,234)=7.918\right.$, $\mathrm{p}<.001)$.

Model 4.2a regresyon sonucuna göre Görev Odaklı Liderlik $(\beta=.232, t(234)=2.411, p<.05)$ Görev Performansı sonuçlarını pozitif yönde etkilemektedir. Sonuçlara göre Değişim Odaklı Liderlik ve İlişki Odaklı Liderliğin Görev Performansı üzerinde anlamlı bir etkisi bulunmamaktadır $\left(\mathrm{R}^{2}=.107\right.$, $\mathrm{F}(3,234)=9.366, \mathrm{p}<.001)$.

Model 4.3a regresyon sonucuna göre Görev Odaklı Liderlik $(\beta=.216, t(234)=2.267$, $\mathrm{p}<.05)$ ve İlişki Odaklı Liderlik $(\beta=.236, \mathrm{t}(234)=2.259, \mathrm{p}<.05)$ Algılanan Performans sonuçlarını pozitif yönde etkilemektedir. Sonuçlara göre Değişim Odaklı Liderliğin Algılanan Performans üzerinde anlamlı bir etkisi bulunmamaktadir $\left(\mathrm{R}^{2}=.122, \mathrm{~F}(3,234)=10.855, \mathrm{p}<.001\right)$. 
Yukarıdaki sonuçlara göre "Takım Perspektifli Liderlik" değerlendirmesinde $\mathrm{H}_{\text {LIO-PBAG, }} \mathrm{H}_{\text {LGO-PGOR, }} \mathrm{H}_{\text {LGO- }}$ PALG ve H hipotezleri doğrulanmamıştır.

Model 4.1b regresyon sonucuna göre Görev Odaklı Liderlik $(\beta=.325, \mathrm{t}(234)=4.881, \mathrm{p}<.001)$ ve İlişki Odaklı Liderlik $(\beta=.325, \mathrm{t}(234)=4.180, \mathrm{p}<.001)$ Bağlamsal Performans sonuçlarını pozitif yönde etkilemektedir. Sonuçlara göre Değişim Odaklı Liderliğin, Bağlamsal Performans üzerinde anlamlı bir etkisi bulunmamaktadır $\left(\mathrm{R}^{2}=.408, \mathrm{~F}(3,234)=53.700, \mathrm{p}<.001\right)$.

Model 4.2b regresyon sonucuna göre Görev Odaklı Liderlik $(\beta=.455, \mathrm{t}(234)=7.833 \mathrm{p}<.001)$ ve İlişki Odaklı Liderlik $(\beta=.440, \mathrm{t}(234)=6.483, \mathrm{p}<.001)$ Görev Performansı sonuçlarını pozitif yönde etkilemektedir. Değişim Odaklı Liderlik $(\beta=.-146, t(234)=-2.586, p<.05)$ ise Görev Performansı sonucunu anlamlı biçimde negatif etkilemektedir $\left(\mathrm{R}^{2}=.548, \mathrm{~F}(3,234)=94.511, \mathrm{p}<.001\right)$. Değişim Odaklı Liderliğin beklenenin aksine anlamlı ve aynı zamanda negatif etkisi tartışılması gereken bir sonuçtur.

Model 4.3b regresyon sonucuna göre Görev Odaklı Liderlik $(\beta=.434, \mathrm{t}(234)=7.708, \mathrm{p}<.001)$ ve İlişki Odaklı Liderlik $(\beta=.425, \mathrm{t}(234)=6.471, \mathrm{p}<.001)$ Algılanan Performans sonuçlarını pozitif yönde etkilemektedir. Sonuçlara göre Değişim Odaklı Liderliğin Algılanan Performans üzerinde anlamlı bir etkisi bulunmamaktadır $\left(\mathrm{R}^{2}=.576, \mathrm{~F}(3,234)=106.107, \mathrm{p}<.001\right)$.

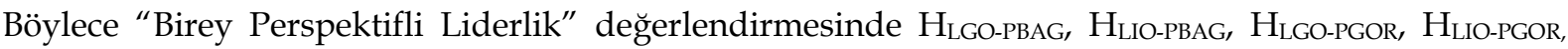
$\mathrm{H}_{\text {LGO-PALG }}$ ve $\mathrm{H}_{\text {LIO-PALG }}$ hipotezleri kabul edilirken; $\mathrm{H}_{\text {LDO-PGOR, }} \mathrm{H}_{\text {LDO-PBAG }}$ ve $\mathrm{H}_{\text {LDO-PALG }}$ hipotezleri reddedilmiştir.

\section{Araştırma bulguları ve sonuçlar}

\section{Araştırma sonuçlarının değerlendirilmesi}

Önceki bölümlerde ifade edildiği gibi analizler iki liderlik değerlendirmesinde öncelikli olarak “Takım Perspektifli" değerlendirmeyi baz alsa da "Birey Perspektifli" değerlendirme yöntemi de analize dahil edilmiştir. Böylece iki farklı değerlendirme yöntemine göre sonuçların nasıl değiştiği de ayrı bir çözümleme konusu olmuştur. Tablo 7, hipotezlerin kabul ve ret sonuçlarını özetlemektedir.

Öncelikle sonuçlar Eğitim Literatürünü ve Kirkpatrick eğitim değerlendirme paradigmasını doğrular niteliktedir.

Eğitimi tamamlayan çalışanların, Nesnel Performans ve Yönetici tarafından değerlendirilen Görev Performansı ölçümleri eğitimi tamamlamayan çalışanlara göre daha yüksektir. Bu genel sonuç, literatürdeki çeşitli meta-analiz çalışmalarının (Salas vd., 2008; Singh vd., 2015; Thang vd., 2010) bulgularıla paralellik göstermektedir.

Eğitim Tepkisi, Eğitim İçeriğini Öğrenmeyi pozitif yönde etkilemektedir. Eğitim İçeriğini Öğrenme de Ĕ̆itim Davranış Yansımasını pozitif yönde etkilemektedir. Son olarak -modele Liderlik Davranışlarının Etkisi eklenmiş olsa da- Eğitim Davranış Yansıması Nesnel İş Performansını pozitif yönde etkilemektedir. Kirkpatrick'in varsayımı doğrulanmış, bazı çalışmalarda (Arthur vd., 2003; J. D. Kirkpatrick ve Kirkpatrick, 2010) ampirik ilişkisi temkinli ifade edilen 2. Seviye ve 3. seviye ilişkisi anlamlı sonuç vermiştir. Bunun yanında Alliger ve arkadaşlarının (Alliger vd., 1997) tartıştığı biçimde "Eğitim Tepkisi" ile "Nesnel Performans" doğrudan ilişkilendirilmeye olanak tanımayan biçimde düşük bir ilişki göstermiştir.

İlişki Odaklı Liderlik ve Bağlamsal Performans arasındaki ilişki ile Görev Odaklı Liderlik ve Görev Performansı arasındaki ilişki hem takım hem de birey perspektifli liderlik değerlendirmelerinde literatürü doğrular niteliktedir. Bu ilişki ikilisinin tersi, yani İlişki Odaklı Liderlik ve Görev Performans ile Görev Odaklı Liderlik ve Bağlamsal Performans arasındaki ilişki takım perspektifli değerlendirmede doğrulanmamıştır. Takım perspektifli liderlik değerlendirmesinde doğrulanmayan bu hipotezler, birey perspektifli liderlik değerlendirmelerinde doğrulanmaktadır. İncelenen birçok araştırmanın liderlik değerlendirmelerini birey perspektifli gerçekleştirdiği düşünüldüğünde sonuçların literatürdeki bazı iki boyutlu liderlik çalışmalarıyla (Burke vd., 2006; Fisher ve Edwards, 1988; Özdevecioğlu ve Kanıgür, 2009) paralel olduğu söylenebilir. 
Tablo 7. Hipotezlerin Kabul ve Ret Sonuçları

\begin{tabular}{|c|c|c|c|}
\hline Model & Hipotez & $\begin{array}{l}\text { Takım Perspektifli } \\
\text { Liderliğe Göre }\end{array}$ & $\begin{array}{l}\text { Birey Perspektifli } \\
\text { Liderliğe Göre }\end{array}$ \\
\hline Model 1 & $\begin{array}{l}\text { HEMEM-EOGR: Çalışanın eğitim memnuniyeti, eğitim içeriğini } \\
\text { öğrenmesini pozitif yönde etkiler. }\end{array}$ & \multicolumn{2}{|c|}{$\mathrm{Kabul}^{* *}$} \\
\hline Model 1 & $\begin{array}{l}\text { HEIK-EOGR: Çalışanın eğitim ihtiyaçlarının karşılanması, eğitim } \\
\text { içeriğini öğrenmesini pozitif yönde etkiler }\end{array}$ & \multicolumn{2}{|c|}{ Kabul $^{* *}$} \\
\hline Model 2.1 & $\begin{array}{l}\text { HEOGR-ETRA: Çalışanın eğitim içeriğini öğrenmesi, eğitim } \\
\text { transferini pozitif yönde etkiler. }\end{array}$ & \multicolumn{2}{|c|}{ Kabul $^{* *}$} \\
\hline Model 2.2 & $\begin{array}{l}\text { HEOGR-EDD: Çalışanın eğitim içeriğini öğrenmesi, eğitim davranış } \\
\text { değişimini pozitif yönde etkiler. }\end{array}$ & \multicolumn{2}{|c|}{$\mathrm{Kabul}^{* *}$} \\
\hline $\begin{array}{l}\text { Model 3a } \\
\text { Model 3b }\end{array}$ & $\begin{array}{l}\text { HETRA-PNEs: Çalışanın eğitim transferi, nesnel performansını } \\
\text { pozitif yönde etkiler. }\end{array}$ & Kabul $^{* *}$ & Ret \\
\hline $\begin{array}{l}\text { Model 3a } \\
\text { Model 3b }\end{array}$ & $\begin{array}{l}\text { HeDD-PNES: Çalışanın eğitim davranış değişimi, nesnel } \\
\text { performansını pozitif yönde etkiler. }\end{array}$ & $\mathrm{Kabul}^{* *}$ & Kabul $^{*}$ \\
\hline $\begin{array}{l}\text { Model 3a } \\
\text { Model 3b }\end{array}$ & $\begin{array}{l}\text { HLGO-PNES: Görev odaklı liderlik davranışı, çalışanın nesnel } \\
\text { performansını pozitif yönde etkiler. }\end{array}$ & Ret & Ret \\
\hline $\begin{array}{l}\text { Model 3a } \\
\text { Model 3b }\end{array}$ & $\begin{array}{l}\text { HLIO-PNEs: İlişki odaklı liderlik davranışı, çalışanın nesnel } \\
\text { performansını pozitif yönde etkiler. }\end{array}$ & Ret & Kabul $^{*}$ \\
\hline $\begin{array}{l}\text { Model 3a } \\
\text { Model 3b }\end{array}$ & 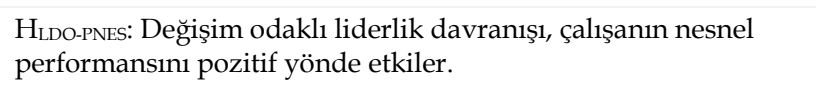 & Ret & Ret \\
\hline $\begin{array}{l}\text { Model 4.1a } \\
\text { Model 4.1b }\end{array}$ & $\begin{array}{l}\text { HLGO-PBAG: Görev odaklı liderlik davranışı, çalışanın bağlamsal } \\
\text { performansını pozitif yönde etkiler. }\end{array}$ & Ret & Kabul $^{* *}$ \\
\hline $\begin{array}{l}\text { Model 4.1a } \\
\text { Model 4.1b }\end{array}$ & $\begin{array}{l}\text { HLIO-PBAG: İlişki odaklı liderlik davranışı, çalışanın bağlamsal } \\
\text { performansını pozitif yönde etkiler. }\end{array}$ & Kabul $^{*}$ & Kabul $^{* *}$ \\
\hline $\begin{array}{l}\text { Model 4.1a } \\
\text { Model 4.1b }\end{array}$ & 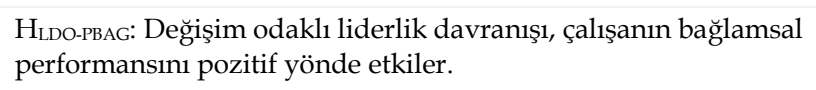 & Ret & Ret \\
\hline $\begin{array}{l}\text { Model 4.2a } \\
\text { Model 4.2b }\end{array}$ & $\begin{array}{l}\text { HLGO-PGOR: Görev odaklı liderlik davranışı, çalışanın görev } \\
\text { performansını pozitif yönde etkiler. }\end{array}$ & Kabul $^{*}$ & Kabul $^{* *}$ \\
\hline $\begin{array}{l}\text { Model 4.2a } \\
\text { Model 4.2b }\end{array}$ & $\begin{array}{l}\text { HLıO-PGOR: İlişki odaklı liderlik davranışı, çalışanın görev } \\
\text { performansını pozitif yönde etkiler. }\end{array}$ & Ret & Kabul $^{* *}$ \\
\hline $\begin{array}{l}\text { Model 4.2a } \\
\text { Model 4.2b }\end{array}$ & $\begin{array}{l}\text { HLDO-PGOR: Değişim odaklı liderlik davranışı, çalışanın görev } \\
\text { performansını pozitif yönde etkiler. }\end{array}$ & Ret & Ret \\
\hline $\begin{array}{l}\text { Model 4.3a } \\
\text { Model 4.3b }\end{array}$ & $\begin{array}{l}\text { HLGO-PALG: Görev odaklı liderlik davranışı, çalışanın algılanan } \\
\text { performansını pozitif yönde etkiler. }\end{array}$ & Kabul $^{*}$ & $\mathrm{Kabul}^{* *}$ \\
\hline $\begin{array}{l}\text { Model 4.3a } \\
\text { Model 4.3b }\end{array}$ & $\begin{array}{l}\text { HLIO-PALG: İlişki odaklı liderlik davranışı, çalışanın algılanan } \\
\text { performansını pozitif yönde etkiler. }\end{array}$ & Kabul $^{*}$ & Kabul $^{* *}$ \\
\hline $\begin{array}{l}\text { Model 4.3a } \\
\text { Model 4.3b }\end{array}$ & $\begin{array}{l}\text { HLDO-PALG: Değisşim odaklı liderlik davranışı, çalışanın algılanan } \\
\text { performansını pozitif yönde etkiler. }\end{array}$ & Ret & Ret \\
\hline
\end{tabular}

Takım perspektifli liderlik değerlendirmesiyle birey perspektifli liderlik değerlendirmesinin farklı hipotez sonuçları verdiği analizler incelendiğinde; İlişki Odaklı Liderliğin Nesnel Performansı ve Görev Performansını etkileme hipotezi ile Görev Odaklı Liderliğin Bağlamsal Performansı etkileme hipotezinin iki perspektifte farklı sonuç verdiği görülebilir. Her üç ilişkide de "Takım Perspektifli" değerlendirmede hipotez reddedilirken, "Birey Perspektifli" değerlendirmede hipotez kabul edilmiştir.

$\mathrm{Bu}$ sonucu yorumlarken; takım perspektifli değerlendirmenin "liderin gerçekte ne olduğu", birey perspektifli değerlendirmenin ise "liderin takipçisi tarafından nasıl görüldüğü" temel varsayımları yardımcı olabilir.

Takım perspektifli değerlendirmede pozitif bir ilişki ortaya çıkması için liderin "bireye nasıl göründüğünden" çok "ne olduğu" konusunda takımda güçlü bir uzlaşma gerekir. İki perspektifin değerlendirilmeleri, liderin bireyler tarafından algılanış biçimindeki ciddi farklılıkları ortaya 
koymaktadır. Elbette liderlik doğası gereği bireyleri etkilemeyi içermektedir ve bu sebeple bireyin algısı belirleyici bir etkendir. Bununla birlikte liderlik kavramsallaştırmalarının çoğu, lideri tutarlı davranışlar sergileyen bir etkileme kaynağı olarak ele almaktadır. Araştırma sonuçları bu iki varsayımın zaman zaman çelişkili olabileceğini göstermektedir.

Hipotez sonuçlarından liderlikle ilişkili olanlar değerlendirildiğinde, "Takım Perspektifli" veya "Birey Perspektifli" değerlendirme fark etmeksizin; Değişim Odaklı Liderliğin modellerde beklenen sonucu verememiş olduğu, hatta bir ilişkide anlamlı ve negatif biçimde performansı etkilediği tespit edilmiştir. İncelenen çalışmalarda buna benzer sonuçlar (Cummings vd., 2010, 2018; Mekraz ve Gundala, 2016) gözlemlenmiş olsa da literatürde yer alan çalışmalarda genel eğilim tersi yöndedir. Bu sonucun birçok nedeni olabilir. Sağduyulu bir çözümleme; yenilikçilik veya vizyonerlik gerektirmeyen iş alanlarında "Değişim Odaklılığın" performans artırıcı rol oynamıyor olmasına dayanır. Diğer bir ifade ile "Değişim Odaklı Liderin" başarılı olabilmesi için belki de alt düzey yönetici gibi kısıtlı bir iş alanı ve buna bağlı sorumluluklar yerine üst düzey yönetici gibi daha karmaşık sorumluluk ve yetkiyle donatılmış olması gerekiyor olabilir. "Değişim gerçekleştirme" yetkisi sınırlı liderler için etki alanı kısıtlı olabilir.

Bir diğer incelenmesi gereken sonuç, Görev Odaklı Liderliğin Nesnel Performans üzerine etkili olmamasıdır. Aynı veri seti üzerinden yapılan alternatif modellemelerde Eğitim Değişkenleri çıkarıldığında hem takım perspektifli hem de birey perspektifli liderlik değerlendirmelerinde Görev Odakı Liderliğin Nesnel Performansı etkileyen sonuçlar çıkardığı tespit edilmiştir. Bu durum, modele eğitim davranış yansımalarının eklenmesiyle Görev Odaklı Liderliğin etkisinin görece azaldığını, diğer bir deyişle Görev Odaklı Liderliğin Eğitim Davranış Yansıması kadar sonuçları etkilemediği olarak yorumlanabilir.

Nesnel Performans ile Görev Performansı arasında orta, Bağlamsal Performans arasında düşük bir korelasyon tespit edilmiştir. Bunlara paralel biçimde, Nesnel Performans ile genel Algılanan (Öznel) Performans arasında da anlamlı ama düşük seviyede bir ilişki tespit edilmiştir. Ama bu ilişkiler iki öznel değişken olan; Görev Performansı ile Bağlamsal Performans arasındaki korelasyondan $(\mathrm{r}(238)=.690$, p<.01) daha yüksek değildir. Bu bağlamda sonuçlar literatürdeki benzer çalışmalarla (Bommer vd., 1995; Jaramillo vd., 2005; Lowery ve Krilowicz, 1994; Plouffe vd., 2009; Rich vd., 1999) paralellik göstermektedir.

Araştırma, literatürde en çok tartışılan konulardan birini de inceleme fırsatı bulmuştur. Sonuçlara göre çalışanların kendini değerlendirdiği öznel performans değerlendirmelerinin ortalamaları, yönetici değerlendirmelerine göre anlamlı biçimde yüksektir. Bununla birlikte, iki perspektif arasında hem Görev Performansı hem de Bağlamsal Performans değerlendirmelerinde orta düzeyde korelasyon tespit edilmiştir. Sonuçlar Churchill, Kuvaas ve Sharma'nın (Churchill vd., 1985; Kuvaas ve Dysvik, 2009; Sharma vd., 2004) iddialarını destekler niteliktedir.

\section{Kısıtlar ve gelecek araştırmalar için öneriler}

Çalışmanın en dikkat çekici sonuçlarından biri takım perspektifli liderlik değerlendirmesi ile birey perspektifli değerlendirmeler arasında ciddi farklılıkların oluşmasıdır. Literatürde takım perspektifli değerlendirmelerin gerekliliğine dair bazı öneriler bulunsa da ampirik anlamda bu yaklaşımın kullanılmasına çok sık rastlanmamaktadır. Gelecek araştırmalar iki perspektifin farklarını ve bu farklılığın kavramsal temellerini daha detaylı ele alabilir.

"Değişim Odaklı Liderlik" için önceki çalışmaların referansıyla hipotezlenen hiçbir ilişki doğrulanmamış olmasıdır. Literatürdeki yaygın bulguların aksine; Değişim Odaklı Liderlik ve performans değişkenleri arasında ilişkinin oluşmaması, hatta bir ilişkinin negatif ve anlamlı sonuç vermesi dikkate değer bir durumdur ve ek incelemeler gerektirmektedir.

En önemli araştırma kıstı, çalışmanın tek bir eğitim tipi için test edilmiş olmasıdır. Bulguların genelleştirilebilmesi için gelecek araştırmalarda farklı eğitim tipleri ve farklı iş alanlarında uyarlanması gerekmektedir.

Ayrıca bu araştırma özelinde Eğitim İçeriğini Öğrenme, Eğitim Transferi ve Eğitim Davranış Değişimi belirli hedefleri olan bir eğitimin tüm modüllerini kapsayan bir bakış açısına sahiptir. Modüllerin veya odak çalışma alanlarının birbiriyle farklı sonuç doğurabilme ihtimali bulunmaktadır. Gelecekte araştırmalar, bütünsel sonuçlar yerine, eğitime konu olan bilgi, beceri ve yetenekler için ayrı ayrı ilişkileri inceleyerek daha spesifik sonuçlar elde edebilir.

Son olarak, birçok araştırmada olduğu gibi değerlendirmelerin öznelliği kavramın genel doğrulanması için bir risk oluşturmaktadır. 


\section{Uygulayıcılar için öneriler}

Eğitim ve Geliştirme çalışmalarının, nesnel performansa olumlu etkisi bulunmaktadır. Bu etkinin başka öncüllere de bağlı olma ihtimali bulunmakla birlikte, sağduyulu bakış açısına göre etkinin temel nedeninin eğitim içeriğinde öğrenilen bilgi, beceri ve yetenekler olduğu düşünülmelidir.

Eğitimin ilk tepkisi ile öğrenme arasında pozitif bir ilişkinin varlığı eğitim tepkilerini "sevimli gülen adam" anketlerinden daha önemli bir yere oturtmaktadır. Eğitim tepkileri dikkatli incelenmeli, olumsuzluklar hızlı biçimde çözülmelidir.

Görev Odaklı Liderlik Görev Performansını, İlişki Odaklı Liderlik Bağlamsal Performansı olumlu etkiliyor görünmektedir. Her iki liderlik türü bir arada genel Algılanan Performansı etkilemektedir. Bu sonucun özet bir reçeteyi çă̆rıştırdığını söylemek yanlış olmaz: İnsan ilişkilerini ön planda tutan liderler, çalışanlar arasında yardımlaşmayı, fedakarlığı ve takım ruhunu artırmayı başarmaktadır. Denetim, planlama gibi davranışları odağında tutan liderler ise takipçilerinin görev performansını artırmaktadır. Her iki yaklaşımın bir arada kullanılmasının ortalamada her iki performansın da artışıyla sonuçlandırması muhtemeldir.

Nedensellik ilişkisinden bağımsız, Algılanan (Öznel) Görev Performansı ve Bağlamsal Performans ile Nesnel Performans arasında bir ilişki bulunmaktadır. Bu ilişki Görev Performansı ile Nesnel Performans arasında daha yüksektir. Bu sonuç öznel değerlendirmelerin uygun şartlar sağlandığında nesnel değerlendirmeler yerine kullanılabileceği şeklinde yorumlanabilir.

Çalışanların performanslarını değerlendirirken, çalışanların kendi görüşlerine başvurulması bazı beklentilerin aksine anlamsız sonuçlar doğurmamakta, sadece yönetici değerlendirmelerine göre daha yüksek bir ortalamaya sahip olmaktadır. Her iki ölçüm kaynağının bir arada kullanılmadığı, sadece çalışanın değerlendirmesinin dahil edildiği ölçümlerde, ödüllendirme veya benzer araçların seviyelerinin tespitinde dikkatli olunmalıdır.

Liderler veya yöneticiler hakkındaki görüşlerin değerlendirilmelerinde ise lidere bağlı çalışanların birbirlerinden farklı bir lider algısına sahip olduğu görülmüştür. Bu durumda; örneğin liderin kendisinin değerlendirildiği durumlar için takipçilerin ölçüm ortalamalarının alınması, liderin çalışan ile geribildirim toplantısı gerçekleştirmesi durumunda o ise o çalışanın lider değerlendirmesinin baz alınması işlevsel gözükmektedir.

Bu araştırma sonuçlarına göre, hem görev ve ilişki odaklı liderlik davranışları hem de eğitim faaliyetleri performansı olumlu yönde etkilemektedir. Söz konusu nesnel performans olduğunda ise bu etki sadece eğitim faaliyetleri için geçerlidir.

Bu sonuç, uygulamada "iyi/ideal" bir liderin birey ve takım başarısı için yeterli olmadığını, iyi planlanmış yetenek geliştirme eğitimlerinin ise sonuçları olumlu değiştirebilecek etkiye sahip olduğunu göstermektedir.

\section{Hakem Değerlendirmesi / Peer-review:}

Dış bağımsız

Externally peer-reviewed

\section{Çıkar Çatışması / Conflict of interests:}

Yazarlar çıkar çatışması bildirmemiştir.

The authors have no conflict of interest to declare.

\section{Finansal Destek / Grant Support:}

Yazarlar bu çalışma için finansal destek almadığını beyan etmiştir.

The authors declared that this study has received no financial support. 


\section{Yazar Katkıları / Author Contributions:}

Fikir/Kavram/Tasarım - Idea/Concept/Design: E.Ü., O.E. Veri Toplama ve/veya İşleme - Data Collection and/or Processing: E.Ü. Analiz ve/veya Yorum - Analysis and/or Interpretation: E.Ü., O.E., H.I. Kaynak Taraması - Literature Review: E.Ü., O.E. Makalenin Yazımı - Writing the Article: E.Ü. Eleştirel İnceleme Critical Review: O.E., H.I. Onay - Approval: O.E., H.İ., E.Ü.

\section{Kaynakça / References}

Alliger, G. M., ve Janak, E. A. (1989). Kirkpatrick's Levels Of Training Criteria: Thirty Years Later. Personnel Psychology, 42, 331-342.

Alliger, G. M., Tannenbaum, S. I., Bennett, W., Traver, H., ve Shotland, A. (1997). A Meta-Analysis Of The Relations Among Training Criteria. Personnel Psychology, 50(2), 341-358. https://doi.org/10.1111/j.1744-6570.1997.tb00911.x

Anderson, E., ve Oliver, R. L. (1987). Perspectives on Behavior-Based versus Outcome-Based Salesforce Control Systems. Journal of Marketing, 51(4), 76-88. https:// doi.org/10.2307/1251249

Arthur, W., Bennett, W., Edens, P. S., ve Bell, S. T. (2003). Effectiveness of training in organizations: A meta-analysis of design and evaluation features. Journal of Applied Psychology, 88(2), 234-245. https://doi.org/10.1037/0021-9010.88.2.234

Avolio, B. J., ve Bass, B. M. (2002). Developing Potential Across A Full Range Of Leadership: Cases on Transactional and Transformational Leadership. Lawrence Erlbaum Associates.

Bass, B. M., ve Bass, R. (2008). The Bass Handbook of Leadership: Theory, Research, and Managerial Applications (4th bask1). Free Press.

Behrman, D. N., ve Perreault, W. D. (1982). Measuring the Performance of Industrial Salespersons. Journal of Business Research, 10(3), 355-370.

Bell, B. S., Tannenbaum, S. I., Kevin Ford, J., Noe, R. A., ve Kraiger, K. (2017). 100 Years Of Training And Development Research: What We Know And Where We Should Go. Journal of Applied Psychology, 102(3), 305-323. https:// doi.org/10.1037/ap10000142

Binning, J. F., ve Barrett, G. V. (1989). Validity of Personnel Decisions: A Conceptual Analysis of the Inferential and Evidential Bases. Journal of Applied Psychology, 74(3), 478-494. https://doi.org/10.1037/0021-9010.74.3.478

Boles, J. S., Donthu, N., ve Lohtia, R. (1995). Salesperson evaluation using relative performance efficiency: The application of data envelopment analysis. Journal of Personal Selling and Sales Management, 15(3), 31-49. https:// doi.org/10.1080/08853134.1995.10754027

Bommer, W. H., Johnson, J. L., Rich, G. A., Podsakoff, P. M., ve Mackenzie, S. B. (1995). On the Interchangeability of Objective and Subjective Measures of Employee Performance: a Meta-Analysis. Personnel Psychology, 48(3), 587-605.

Borgmann, L., Rowold, J., ve Bormann, K. C. (2016). Integrating leadership research: a meta-analytical test of Yukl's meta-categories of leadership. Personnel Review, 45(6), 1340-1366. https://doi.org/10.1108/PR-07-2014-0145

Borman, W. C., ve Motowidlo, S. J. (1997). Task Performance and Contextual Performance: The Meaning for Personnel Selection Research. Human Performance, 10(2), 99-109.

Brief, A. P., ve Motowidlo, S. J. (1986). Prosocial Organizational Behaviors. Academy of Management Review, 11(4), 710-725.

Brogden, H. E., ve Taylor, E. K. (1950). The Dollar Criterion - Applying the Cost Accounting Concept to Criterion Construction. Personnel Psychology, 3, 133-154.

Burke, C. S., Stagl, K. C., Klein, C., Goodwin, G. F., Salas, E., ve Halpin, S. M. (2006). What type of leadership behaviors are functional in teams? A meta-analysis. Leadership Quarterly. https://doi.org/10.1016/j.leaqua.2006.02.007

Campbell, J. P., Gasser, M. B., ve Oswald, F. L. (1996). The Substantive Nature of Job Performance Variability. Içinde K. R. Murphy (Ed.), Individual Differences and Behavior in Organizations. Jossey-Bass Inc. 
Campbell, J. P., ve Wiernik, B. M. (2015). The Modeling and Assessment of Work Performance. Içinde Annual Review of Organizational Psychology and Organizational Behavior (C. 2, Say1 1). https://doi.org/10.1146/annurev-orgpsych-032414-111427

Castleberry, S. B., ve Tanner, J. F. (2011). Selling Building Partnerships (8th bask1). McGraw-Hill/Irwin.

Churchill, G. A., Ford, N. M., Hartley, S. W., ve Walker, O. C. (1985). The Determinants of Salesperson Performance: A Meta-Analysis. Journal of Marketing Research, 22(2), 103. https:/ / doi.org/10.2307/3151357

Conway, J. M., ve Huffcutt, A. I. (1997). Psychometric Properties of Multisource Performance Ratings: A meta-Analysis of Subordinate, Supervisor, Peer, and Self-Ratings. Human Perfomance, 10(4), 331360.

Cooper, W. H. (1981). Ubiquitous Halo. Psychological Bulletin, 90(2), 218-244. https://doi.org/10.1037/0033-2909.90.2.218

Cummings, G. G., MacGregor, T., Davey, M., Lee, H., Wong, C. A., Lo, E., Muise, M., ve Stafford, E. (2010). Leadership styles and outcome patterns for the nursing workforce and work environment: A systematic review. International Journal of Nursing Studies, 47(3), 363-385. https://doi.org/10.1016/j.ijnurstu.2009.08.006

Cummings, G. G., Tate, K., Lee, S., Wong, C. A., Paananen, T., Micaroni, S. P. M., ve Chatterjee, G. E. (2018). Leadership styles and outcome patterns for the nursing workforce and work environment: A systematic review. International Journal of Nursing Studies, 85(April), 19-60. https://doi.org/10.1016/j.ijnurstu.2018.04.016

Damayanti, R. W., Hartono, B., Wijaya, A. R., Helmi, A. F., ve Riyono, B. (2019). A Meta Analysis Study Leadership and Project Success. International Conference on Industrial Enterprise and System Engineering, 2, 369-374. https://doi.org/10.2991/icoiese-18.2019.65

DeClerk, C. C. (2007). The relationship between retail store manager leadership styles and employee generational cohort, performance, and satisfaction. UNIVERSITY OF PHOENIX.

Ekvall, G., ve Arvonen, J. (1991). Change-centered leadership: An extension of the two-dimensional model. Scandinavian Journal of Management, 7(1), 17-26. https://doi.org/10.1016/09565221(91)90024-U

Ererdi, C., ve Durgun, E. Ü. (2020). Conceptual Review of Leadership on Organizational Performance. Business $\mathcal{E}$ Management Studies: An International Journal, 8(1), 1044-1095. https://doi.org/10.15295/bmij.v8i1.1336

Erffmeyer, R. C., Russ, K. R., ve Hair, J. F. (1991). Needs Assessment and Evaluation in Sales-Training Programs. Journal of Personal Selling and Sales Management, 11(1), 17-30. https://doi.org/10.1080/08853134.1991.10753856

Fernandez, S. (2008). Examining the Effects of Leadership Behavior on Employee Perceptions of Performance and Job Satisfaction. Public Performance $\mathcal{E}$ Management Review, 32(2), 175-205. https://doi.org/10.2753/pmr1530-9576320201

Fisher, B. M., ve Edwards, J. E. (1988). Consideration and Initiating Structure and Their Relationships With Leader Effectiveness: A Meta-Analysis. Academy of Management Proceedings, 1988(1), 201-205. https://doi.org/10.5465/ambpp.1988.4980535

Futrell, C. M. (2011). Fundamental of Selling (12th bask1). McGraw-Hill/Irwin.

Goldstein, I. L. (1980). Training in Work Organizations. Annual Review of Psychology, 31, $229-272$.

Goodman, S. A., ve Svyantek, D. J. (1999). Person - Organization Fit and Contextual Performance : Do Shared Values Matter. Journal of Vocational Behavior, 55, 254-275.

Harari, M. B., Reaves, A. C., ve Viswesvaran, C. (2016). Creative and innovative performance: a metaanalysis of relationships with task, citizenship, and counterproductive job performance dimensions. European Journal of Work and Organizational Psychology, 25(4), 495-511. https://doi.org/10.1080/1359432X.2015.1134491

Ingram, T. N., LaForge, R. W., Avila, R. A., Schwepker, C. H., ve Williams, M. R. (2020). Sales Management: Analysis and Decision Making (10th bask1). Routledge.

Jaramillo, F., Carrillat, F. A., ve Locander, W. B. (2003). Starting to Solve the Method Puzzle in 
Salesperson Self-Report Evaluations. The Journal of Personal Selling and Sales Management, 23(4), 369377.

Jaramillo, F., Carrillat, F. A., ve Locander, W. B. (2004). Response to Comment: Starting to Solve the Method Puzzle in Salesperson Self-Report Evaluations. The Journal of Personal Selling and Sales Management, 24(2), 141-145.

Jaramillo, F., Carrillat, F. A., ve Locander, W. B. (2005). A Meta-Analytic Comparison of Managerial Ratings and Self-Evaluations. The Journal of Personal Selling and Sales Management, 25(4), 315-328.

Johnston, M. W., ve Marshall, G. W. (2016). Sales Force Management : Leadership, Innovation, Technology (12th bask1). Routledge.

Kilburn, B. R. (2007). The Effects of Leader Behavior on Follower Attitudes and Intentions Toward the Provision of Voluntary Upward Feedback. The University of Memphis.

Kirkpatrick, D. L. (1977). Evaluating Training Programs: Evidence vs. Proof. Training and Development Journal, 31(11), 9-12.

Kirkpatrick, D. L., ve Kirkpatrick, J. D. (2006). Evaluating Training Programs: The Four Levels (3rd (Ed.)). Berrett-Koehler Publishers.

Kirkpatrick, D. L., ve Kirkpatrick, J. D. (2007). Implementing The Four Levels A Practical Guide for Effective Evaluation of Training Programs. Berrett-Koehler Publishers.

Kirkpatrick, J. D., ve Kirkpatrick, W. K. (2010). Training On Trial How Workplace Learning Must Reinvent Itself to Remain Relevant. Amacom.

Kuvaas, B., ve Dysvik, A. (2009). Perceived investment in employee development, intrinsic motivation and work performance. Human Resource Management Journal. https://doi.org/10.1111/j.17488583.2009.00103.x

Levy, M., ve Sharma, A. (1993). Relationships Among Measures of Retail Salesperson Performance. Journal of the Academy of Marketing Science, 21(3), 231-238. https://doi.org/10.1177/0092070393213006

Lowery, C. M., ve Krilowicz, T. J. (1994). Relationships among Nontask Behaviors, Rated Performance, and Objective Performance Measures. Psychological Reports, 74(2), 571-578. https://doi.org/10.2466/pr0.1994.74.2.571

MacKenzie, S. B., Podsakoff, P. M., ve Fetter, R. (1991). Organizational citizenship behavior and objective productivity as determinants of managerial evaluations of salespersons' performance. Organizational Behavior and Human Decision Processes, 50(1), 123-150. https://doi.org/10.1016/07495978(91)90037-T

MacKenzie, S. B., Podsakoff, P. M., ve Fetter, R. (1993). The Impact of Organizational Citizenship Behavior on Evaluations of Salesperson Performance. Journal of Marketing, 57(1), 70-80. https://doi.org/10.1177/002224299305700105

MacKenzie, S. B., Podsakoff, P. M., ve Rich, G. A. (2001). Transformational and transactional leadership and salesperson performance. Journal of the Academy of Marketing Science, 29(2), 115-134. https://doi.org/10.1177/03079459994506

Mekraz, A., ve Gundala, R. R. (2016). Leadership Style and Retail Store Performance - A Case Study of Discount Retail Chain. Journal of Business and Retail Management Research, 10(2), 1-10.

Michel, J. W., Lyons, B. D., ve Cho, J. (2011). Is the Full-Range Model of Leadership Really a Full-Range Model of Effective Leader Behavior? Journal of Leadership and Organizational Studies, 18(4), 493-507. https://doi.org/10.1177/1548051810377764

Motowidlo, S. J. (2000). Some Basic Issues Related to Contextual Performance and Organizational Citizenship Behavior in Human Resource Management. Human Resource Management Review, 10(1), 115-126. https:// doi.org/10.1016/S1053-4822(99)00042-X

Murphy, K. R. (1990). Job Performance and Productivity. Içinde K. R. Murphy \& F. E. Saal (Ed.), Psychology in Organizations: Integrating Science and Practice (ss. 157-178).

Northouse, P. G. (2016). Leadership:Theory and Practice (7th bask1). SAGE Publications. https://doi.org/2016

Organ, D. W. (1997). Organizational Citizenship Behavior: It's Construct Clean-Up Time. Human 
Performance, 10(2), 85-97. https://doi.org/10.1207/s15327043hup1002

Organ, D. W. (2018). Organizational Citizenship Behavior: Recent Trends and Developments. Annual Review of Organizational Psychology and Organizational Behavior, 5(1), 295-306.

Organ, D. W., Podsakoff, P. M., ve MacKenzie, S. B. (2006). Organizational Citizenship Behavior: Its Nature, Antecedents, and Consequence. SAGE Publications, Inc.

Özdevecioğlu, M., ve Kanıürr, S. (2009). Çalışanların İlişki ve Görev Yönelimli Liderlik Algılamalarının Performansları Üzerindeki Etkileri. KMU İ̈BF Dergisi, 11(16), 53-82.

Plouffe, C. R., Hulland, J., ve Wachner, T. (2009). Customer-directed Selling behaviors and performance: A comparison of existing perspectives. Journal of the Academy of Marketing Science, 37(4), 422-439. https://doi.org/10.1007/s11747-009-0142-4

Podsakoff, N. P., Whiting, S. W., Podsakoff, P. M., ve Blume, B. D. (2009). Individual- and Organizational-Level Consequences of Organizational Citizenship Behaviors: A Meta-Analysis. Journal of Applied Psychology, 94(1), 122-141. https://doi.org/10.1037/a0013079

Podsakoff, P. M., Scott B. MacKenzie, Paine, J. B., ve Bachrach, D. G. (2000). Organizational Citizenship Behaviors: A Critical Review of the Theoretical and Empirical Literature and Suggestions for Future Research Philip. Journal of Management, 26(3), 513-563. https:// doi.org/10.1016/0009-2614(78)855523

Porr, D., ve Fields, D. (2006). Implicit leadership effects on multi-source ratings for management development. Journal of Managerial Psychology, 21(7), 651-668. https://doi.org/10.1108/02683940610690196

Rich, G. A., Bommer, W. H., Mackenzie, S. B., Podsakoff, P. M., ve Johnson, J. L. (1999). Apples and Apples or Apples and Oranges? A Meta-Analysis of Objective and Subjective Measures of Salesperson Performance. Journal of Personal Selling \& Sales Management, 19(4), 41-52.

Rogelberg, S. G. (Ed.). (2007). Encyclopedia of Industrial and Organizational Psychology. SAGE Publications.

Rotundo, M., ve Rotman, J. (2002). Defining and Measuring Individual Level Job Performance: A Review and Integration. Journal of Applied Psychology, 90(5), 225-254.

Rotundo, M., ve Sackett, P. R. (2002). The Relative Importance of Task, Citizenship, and Counterproductive Performance to Global Ratings of Job Performance: A Policy-Capturing Approach. The Journal of Applied Psychology, 87(1), 66-80. https://doi.org/10.1037/0021-9010.87.1.66

Salas, E., DiazGranados, D., Klein, C., Burke, C. S., Stagl, K. C., Goodwin, G. F., ve Halpin, S. M. (2008). Does team training improve team performance? A meta-analysis. Human Factors, 50(6), 903-933. https://doi.org/10.1518/001872008X375009

Salgado, J. F., ve Moscoso, S. (2019). Meta-analysis of interrater reliability of supervisory performance ratings: Effects of appraisal purpose, scale type, and range restriction. Frontiers in Psychology, 10(2281). https://doi.org/10.3389/fpsyg.2019.02281

Schmidt, F. L., ve Kaplan, L. B. (1971). Composite vs. Multiple Criteria: A Review and Resolution of the Controversy. Personnel Psychology, 24(3), 419-434. https://doi.org/10.1111/j.17446570.1971.tb00365.x

Shannahan, K. L. J., Bush, A. J., ve Shannahan, R. J. (2013). Are your salespeople coachable? How salesperson coachability, trait competitiveness, and transformational leadership enhance sales performance. Journal of the Academy of Marketing Science, 41(1), 40-54. https://doi.org/10.1007/s11747-012-0302-9

Sharma, A., Rich, G. A., ve Levy, M. (2004). Comment: Starting to Solve the Method Puzzle in Salesperson Self-Report Evaluations. Journal of Personal Selling and Sales Management, 24(2), 135-139. https://doi.org/10.1080/08853134.2004.10749025

Singh, V. L., Manrai, A. K., ve Manrai, L. A. (2015). Sales training: A state of the art and contemporary review. Journal of Economics, Finance and Administrative Science, 20(38), 54-71. https://doi.org/10.1016/j.jefas.2015.01.001

Smith, C. A., Organ, D. W., ve Near, J. P. (1983). Organizational Citizenship Behavior: Its Nature and Antecedents. Journal of Applied Psychology, 68(4), 653-663.

Soysal, S. (2005). Mağazacılık: Mükemmel Müşteri Hizmeti ve Etkili Satış Teknikleri (10th baskı). Remzi 
Kitabevi.

Spiro, R. L., Rich, G. A., ve Stanton, W. J. (2008). Management of a Sales Force (12th bask1). McGrawHill/Irwin.

Tannenbaum, S. I., Mathieu, J. E., Salas, E., ve Cannon-Bowers, J. A. (1991). Meeting Trainees' Expectations: The Influence of Training Fulfillment on the Development of Commitment, SelfEfficacy, and Motivation. Journal of Applied Psychology, 76(6), 759-769. https://doi.org/10.1037/00219010.76.6.759

Thang, N., Quang, T., ve Buyens, D. (2010). THE RELATIONSHIP BETWEEN TRAINING AND FIRM PERFORMANCE: A LITERATURE Review. Research and Practice in Human Resource Management, 18(January), 36-45.

Tracey, J. B., ve Hinkin, T. R. (1998). Transformational Leadership or Effective Managerial Practices? Group Organization Management, 23(3), 220-236. https://doi.org/10.1177/1059601198233002

Tyagi, P. K. (1985). Relative Importance of Key Job Dimensions and Leadership Behaviors in Motivating Salesperson Work Performance. Journal of Marketing, 49(3), 76-86. https://doi.org/10.2307/1251617

Uçar, A. C., Eren, E., ve Erzengin, E. (2012). Determination of the Relationship Between Leadership Perceptions of Blue Collars and Organizational Outcomes by Using MLQ Analysis. Procedia - Social and Behavioral Sciences, 41, 196-208. https:// doi.org/10.1016/j.sbspro.2012.04.024

Vedamani, G. G. (2017). Retail Management: Functional Principles and Practices (5th bask1). Pearson.

Viswesvaran, C. (1993). Modeling Job Performance: Is There a General Factor? Department of Management and Organizations, June 1993, 146.

Viswesvaran, C., ve Ones, D. S. (2000). Perspectives on Models of Job Performance. International Journal of Selection and Assessment, 8(4), 216-226. https://doi.org/10.1111/1468-2389.00151

Viswesvaran, C., Ones, D. S., ve Schmidt, F. L. (1996). Comparative Analysis of the Reliability of Job Performance Ratings. Journal of Applied Psychology, 81(5), 557-574. https://doi.org/10.1037/00219010.81.5.557

Viswesvaran, C., Schmidt, F. L., ve Ones, D. S. (2005). Is there a general factor in ratings of job performance? a meta-analytic framework for disentangling substantive and error influences. Journal of Applied Psychology, 90(1), 108-131. https://doi.org/10.1037/0021-9010.90.1.108

Wilson, P. H. (1999). A Model of salespeople's training attitudes and related outcomes. University of North Texas.

Wilson, P. H., Strutton, D., ve Farris, M. T. (2002). Investigating the Perceptual Aspect of Sales Training. Journal of Personal Selling and Sales Management, 22(2), 77-86.

Yukl, G. (1999). An Evaluative Essay on Current Conceptions of Effective Leadership. European Journal of Work and Organizational Psychology, 8(1), 33-48. https://doi.org/10.1080/135943299398429

Yukl, G. (2012). Effective Leadership Behavior: What We Know and What Questions Need More Attention. Academy of Management Perspectives, 26(4), 66-85. https:/ / doi.org/10.5465/amp.2012.0088

Yukl, G. (2013). Leadership in Organizations (Global Edition) (8th baskı). Pearson Education.

Yukl, G., Gordon, A., ve Taber, T. (2002). A Hierarchical Taxonomy of Leadership Behavior: Integrating a Half Century of Behavior Research. Journal of Leadership \& Organizational Studies, 9(1), 15-32. https://doi.org/10.1177/107179190200900102

Yukl, G., Mahsud, R., Prussia, G., ve Hassan, S. (2019). Effectiveness of broad and specific leadership behaviors. Personnel Review, 48(3), 774-783. 